Review

\title{
The Remarkable Evolutionary Plasticity of Coronaviruses by Mutation and Recombination: Insights for the COVID-19 Pandemic and the Future Evolutionary Paths of SARS-CoV-2
}

\author{
Grigorios D. Amoutzias ${ }^{1, *(\mathbb{D})}$, Marios Nikolaidis ${ }^{1}$, Eleni Tryfonopoulou ${ }^{2}\left(\mathbb{D}\right.$, Katerina Chlichlia ${ }^{2} \mathbb{D}$, \\ Panayotis Markoulatos ${ }^{3}$ and Stephen G. Oliver ${ }^{4, *}$
}

1 Bioinformatics Laboratory, Department of Biochemistry and Biotechnology, University of Thessaly, 41500 Larissa, Greece; marionik23@gmail.com

2 Laboratory of Molecular Immunology, Department of Molecular Biology and Genetics, Democritus University of Thrace, University Campus-Dragana, 68100 Alexandroupolis, Greece; eltr.mailbox@gmail.com (E.T.); achlichl@mbg.duth.gr (K.C.)

3 Microbial Biotechnology-Molecular Bacteriology-Virology Laboratory, Department of Biochemistry and Biotechnology, University of Thessaly, 41500 Larissa, Greece; markoulatosp@gmail.com

4 Department of Biochemistry, University of Cambridge, Sanger Building, 80 Tennis Court Road, Cambridge CB2 1GA, UK

* Correspondence: amoutzias@bio.uth.gr (G.D.A.); sgo24@cam.ac.uk (S.G.O.)

Citation: Amoutzias, G.D.; Nikolaidis, M.; Tryfonopoulou, E.; Chlichlia, K.; Markoulatos, P.; Oliver, S.G. The Remarkable Evolutionary Plasticity of Coronaviruses by Mutation and Recombination: Insights for the COVID-19 Pandemic and the Future Evolutionary Paths of SARS-CoV-2. Viruses 2022, 14, 78. https://doi.org/10.3390/v14010078

Academic Editors:

Ioannis Karakasiliotis,

Apostolos Beloukas and

Serafeim Chaintoutis

Received: 23 November 2021

Accepted: 31 December 2021

Published: 2 January 2022

Publisher's Note: MDPI stays neutral with regard to jurisdictional claims in published maps and institutional affiliations.

Copyright: (c) 2022 by the authors. Licensee MDPI, Basel, Switzerland. This article is an open access article distributed under the terms and conditions of the Creative Commons Attribution (CC BY) license (https:// creativecommons.org/licenses/by/ $4.0 /)$.

\begin{abstract}
Coronaviruses (CoVs) constitute a large and diverse subfamily of positive-sense singlestranded RNA viruses. They are found in many mammals and birds and have great importance for the health of humans and farm animals. The current SARS-CoV-2 pandemic, as well as many previous epidemics in humans that were of zoonotic origin, highlights the importance of studying the evolution of the entire CoV subfamily in order to understand how novel strains emerge and which molecular processes affect their adaptation, transmissibility, host/tissue tropism, and patho nonhomologous genicity. In this review, we focus on studies over the last two years that reveal the impact of point mutations, insertions/deletions, and intratypic/intertypic homologous and non-homologous recombination events on the evolution of $\mathrm{CoVs}$. We discuss whether the next generations of $\mathrm{CoV}$ vaccines should be directed against other $\mathrm{CoV}$ proteins in addition to or instead of spike. Based on the observed patterns of molecular evolution for the entire subfamily, we discuss five scenarios for the future evolutionary path of SARS-CoV-2 and the COVID-19 pandemic. Finally, within this evolutionary context, we discuss the recently emerged Omicron (B.1.1.529) VoC.
\end{abstract}

Keywords: coronavirus; SARS-CoV-2; COVID-19; evolution; recombination; point mutations; pandemic; vaccines; spike

\section{Introduction}

The outbreak of the coronavirus disease 2019 (COVID-19) pandemic, caused by the severe acute respiratory syndrome coronavirus-2 (SARS-CoV-2) [1-3], has raised several important questions. The most crucial one is how the currently circulating SARS-CoV-2 virus will evolve in the future: Will new mutations or recombination events, even with distantly related human or animal coronaviruses (CoVs) lead to new variants of concern (VoCs) or to variants of high consequence, or even to a new CoV species to which current vaccines may offer no protection? Another related question concerns the development of the next generation of $\mathrm{CoV}$ vaccines and how their long-term efficacies could be improved. In order to answer these and other questions concerning the origin of the virus and the possibility of the emergence of a new epidemic or pandemic in the future [4,5], it is of paramount importance to understand the evolution of CoVs as an entire group (subfamily). To that end, this review focuses on the unprecedented wealth of data generated over the last two years, not only for SARS-CoV-2 but for the entire Orthocoronavirinae subfamily. 


\section{Notable Coronaviruses}

CoVs are found in a wide range of animal species, especially bats and birds. They cause from mild to severe respiratory, enteric, hepatic, or nervous system disorders [6,7]. So far, four of the human CoVs (HCoV-NL63, HCoV-229E, HCoV-OC43, and HCoV-HKU1) cause mild infections such as the seasonal common cold. In contrast, three other human CoVs (i.e., SARS-CoV-1 [8], Middle East respiratory syndrome coronavirus (MERS-CoV) [9], and SARS-CoV-2 [1-3]) have been implicated in severe respiratory and multi-organ disorders [7]. Other $\mathrm{CoVs}$ cause important diseases in farm animals and include swine acute diarrhea syndrome coronavirus (SADS-CoV), swine transmissible gastroenteritis virus (TGEV), porcine epidemic diarrhea virus (PEDV), and avian infectious bronchitis virus (IBV). The murine hepatitis virus (MHV) is one of the best characterized animal CoVs and is an important research model $[7,10]$.

\section{Classification}

CoVs are enveloped, spherical, positive-sense single-stranded RNA viruses [11] that belong to the order Nidovirales, family Coronaviridae, and the subfamily Orthocoronavirinae. Members of the order Nidovirales include viruses with the largest RNA genomes, with sizes ranging from 13 to $41 \mathrm{~kb}[12,13]$. Together with CoVs, toroviruses (the closest relatives of CoVs) and roniviruses constitute the "large" nidoviruses (with genomes sized $>26 \mathrm{~kb}$ ), whereas arteriviruses have much smaller genomes (13-16 kb) [12]. Nidoviruses display a substantial genomic plasticity and resilience [14].

Based on the 2019 International Committee on Taxonomy of Viruses (ICTV) report, the Orthocoronavirinae subfamily includes four genera: Alpha-CoVs with 14 subgenera and 19 species; Beta-CoVs with five subgenera (i.e., Sarbecovirus, Hibecovirus, Nobecovirus, Merbecovirus, and Embecovirus) and 14 species; Gamma-CoVs with three subgenera and five species; Delta-CoVs with three subgenera and seven species [15]. The taxonomy and species demarcations for CoVs were originally based on serological reactivities of the spike proteins, where CoVs were divided into three serogroups [16], but they are now based on genomic criteria and, more specifically, on five replicative peptides (i.e., 3CLpro, NiRAN, RdRp, ZBD, and HEL) common to all Nidovirales. Furthermore, their selection for species demarcation is based on observations that these regions are not involved in cross-species homologous recombination [3]. This taxonomic demarcation is achieved with the DEmARC software $[17,18]$. The cutoff for species demarcation is $90 \%$ amino-acid sequence identity in the abovementioned conserved replicase polypeptides.

In order to classify SARS-CoV-2 genomes, the different mutations that give rise to functional variants are further divided into higher order phylogenetic lineages and clades. Currently, three nomenclature systems are being used: the GISAID (Global Initiative on Sharing All Influenza Data), Nextstrain, and Pango [19-22]. As of 16 December 2021, more than 6.2 million SARS-CoV-2 genomes have been sequenced and deposited in the EpiCoV database of the GISAID [19]. An extensive review of the various clades, their characteristic mutations, and their phenotypic impact is provided in [23]. Variants are also classified by the World Health Organization (WHO) and the Centers for Disease Control and Prevention (CDC) into different categories based on their phenotype [24]. For example, VoCs, such as the Alpha, Beta, Gamma, and Delta SARS-CoV-2 variants (which should not be confused with the Alpha, Beta, Gamma, and Delta CoV genera), may have increased transmissibility, and/or increased pathogenicity, and/or reduced neutralization by antibodies, and/or reduced detection by diagnostic methods. However, the most notable case that has caused alarm around the world is the recently emerged Omicron VoC (B.1.1.529), which was first reported in November 2021. This variant has over 50 mutations compared to the original Wuhan strain, with over 30 of them located at the Spike ORF. The Omicron variant has already been observed to significantly outcompete the existing prevalent, and already very infectious, Delta variant. Omicron cases in the UK are doubling every 2 days, and this variant also has a very high reinfection rate (a 5.4-fold increase over that of Delta) [25]. Accordingly, 26 out of 29 existing monoclonal antibodies (mAbs) that target the receptor 
binding motif (RBM) cannot neutralize Omicron in vitro, although some mAbs that target antigenic sites outside of the RBM still can [26]. Whether Omicron causes lesser or more severe infections will soon be resolved.

The US Food and Drug Administration (FDA) closely monitors circulating variants that due to the specific mutations may escape detection by certain nucleic acid, antigen, or serology tests. For example, the Omicron variant already escapes detection by some standard tests [27]. In addition, certain nucleic acid tests that monitor two or three different regions of the virus may show an apparent absence of target sequences within Spike or nucleocapsid genes. While such failures raise suspicions that the sample contains the Omicron variant, other variants may also cause this pattern of failure in gene detection [27].

\section{Distribution}

CoVs have become a focal point of virus research, especially after the 2002-2003 SARSCoV-1 epidemic. Data collected over the last two decades show that bats and rodents serve as reservoirs for the Alpha and Beta CoV genera, whereas wild birds probably serve as reservoirs for the Gamma and Delta CoV genera [28-31]. The human CoVs have a zoonotic origin, where bats and rodents seem to be the key reservoirs [32,33] with intermediate hosts, such as civets, raccoon dogs, camels, and possibly (the evidence here is weak) pangolins, playing a role in cross-species transmission [31,34-36]. The recent detection of porcine delta coronavirus (PDCoV) and a feline-canine recombinant Alpha-genus $\mathrm{CoV}$ in human patients demonstrate that many more animals may actually serve as either reservoirs or intermediate hosts [37,38]. Other cases of cross-species transmission include the emergence of $\mathrm{HCoV}-\mathrm{OC} 43$ (most probably from a bovine or swine $\mathrm{CoV}$ ), whereas the Embecovirus HCoV-HKU1 is a sister taxon to MHV and rat sialodacryoadenitis virus [32,39].

The animal receptors to which CoVs bind, such as angiotensin-converting enzyme 2 (ACE2) and aminopeptidase $\mathrm{N}(\mathrm{APN})$, are highly conserved in evolutionary terms, and this leads to a high incidence of cross-species infection including from birds to mammals. Such transmission events may either be direct or happen via a number of hosts at intermediate points on the evolutionary scale [31,40-46]. Spill-back infections from humans to other animals (domesticated or wild) that are termed reverse zoonoses have been reported and should be monitored thoroughly [47]. For example, SARS-CoV-2 is able to infect gorillas, dogs, cats, lions, tigers, pumas, cougars, snow leopards, ferrets, deer, and minks [31,48]. There have been cases of SARS-CoV-2 transmission from humans to minks and back to humans [49]. Such events are matters of concern, since mutations acquired in minks might lead to the emergence of vaccine-escaping variants [50]. Concerning the COVID-19 pandemic, the animal reservoir for SARS-CoV-2 is considered (so far) to be the Rhinolophus (horseshoe bat) spp., residing in the wider area of Indochina and Southwest China [46]. However, the documented reverse zoonosis and sustained infection events, especially in deer and minks, suggest that new animal reservoirs may also be established [48,49]. The events that have led to the emergence of the current pandemic virus are still under investigation $[4,5]$.

\section{Genome Architecture}

CoVs have very large genomes compared to other RNA viruses, with a length of $25-32 \mathrm{~Kb}$, consisting of a $5^{\prime}$ untranslated region (UTR), at least six core open reading frames (ORFs) found in all CoVs, a highly variable number of accessory ORFs, and a $3^{\prime}$ UTR $[7,12,51,52]$. This large genome size may provide scope for the evolutionary flexibility required for cross-species adaptation [53]. The genome architecture of CoVs follows a model of division of labor [53].

The first two ORFs, $1 \mathrm{a}$ and $1 \mathrm{~b}$ (which overlap by a few nucleotides), span two-thirds of the genome and encode polyproteins that are cleaved into 16 non-structural peptides (NSPs 1-16), most of which are involved in transcription and replication. ORF1a (NSPs 1-11) is considered to orchestrate the expression of the entire genome, and it also encodes two proteinases. ORF1b (NSPs 12-16) encodes the principal enzymes involved in RNA 
synthesis; these include the RdRp (NSP 12), a helicase (NSP 13), an exonuclease (NSP 14), an endoribonuclease (NSP 15), and a methyl-transferase (NSP 16) [53,54].

The downstream ORFs control genome dissemination [53]. More specifically, the Spike ORF (S) encodes a structural protein that binds to the host receptors and determines the types of cells that can be infected (cell tropism) [55-58] as well as the host range [54,59]. Next, the envelope ORF (E) encodes a protein that is involved in viral envelope curvature, maturation, assembly, release, and pathogenesis [54]. It is followed by the M ORF that encodes a membrane protein that interacts with the virion proteins $\mathrm{S}, \mathrm{E}, \mathrm{N}$, and the viral genomic RNA, nucleating these components at the budding endoplasmic reticulum-Golgi intermediate compartment [54]. The nucleocapsid protein is an RNA-binding protein, encoded by the subsequent ORF N [54]. Thus, the latter four (i.e., S, E, M, and N) of the abovementioned core ORFs each have a structural role.

Lineage-specific accessory ORFs are also present in this virus-dissemination region of the genome, and they may be involved in adaptation to specific hosts, modulation of the interferon signaling pathways, the production of pro-inflammatory cytokines, or the induction of apoptosis $[12,51,54,60,61]$. The accessory ORF6 displays the highest cellular toxicity among all core and accessory ORFs of SARS-CoV-2 [62]. Two recent large-scale computational analyses shed light on the distinct genome architectures and the dynamic evolution of accessory ORFs [52,63].

\section{Evolution by Point Mutations}

CoVs are unusual RNA viruses in possessing a replication proof-reading mechanism conferred by the NSP 14 exonuclease, an enzyme found only in "large" Nidovirales. This significantly reduces their mutation rate to a level that is similar to that of DNA viruses and, thus, allows them to develop some of the largest genomes among all other RNA viruses $[42,53,64-67]$. A recent experimental evolution study under relatively benign conditions estimated a background mutation rate of 2.9-3.7 $\times 10^{-6} / \mathrm{nt} /$ replication cycle for SARS-CoV-2 [68]. This rate is similar to that of another Beta-genus $\mathrm{CoV}$, mouse hepatitis virus (MHV: $3.5 \times 10^{-6} / \mathrm{nt} /$ replication cycle) [69]. Interestingly, the Spike gene has a mutation rate at least $4-5$ times higher than the rest of the genome [68]. The large number of mutations observed in the spike (34/53 total mutations) of the recently emerged Omicron $\mathrm{VoC}$ is congruent with the above studies. At the same time, the relatively low mutation rate of CoVs is also considered their "Achilles' heel" and has been exploited in order to produce the first approved (by the UK) SARS-CoV-2 orally administered antiviral drug: a ribonucleoside analog that introduces copying errors and, thus, dramatically increases the mutation rate of many diverse $\mathrm{CoVs}$ (including MERS-CoV) to a lethal level beyond the error threshold [66,67,70-72].

CoVs would not be expected to rapidly adapt to new environments and hosts via point mutations, unless they have some mechanism that allows them to regulate and increase their mutability in the first phases of host transition. However, the effects of even a few point mutations should not be underestimated, since they can be sufficient to transform a CoV strain with mild symptoms into a strain that may change cell tropism and induce severe systemic pathology. Point mutations (especially in the gene for the spike protein) are capable of increasing replication, transmissibility, and even lead to immune escape [73-75]. A notable example is a Feline $\mathrm{CoV}$ that mutates to a lethal form named feline infectious peritonitis virus (FIPV) by a few point mutations in the C-terminal part of the Spike gene [58]. These mutations affect cell entry and cause a change in cell tropism, from enteric epithelia to macrophages [58].

Thanks to new-generation sequencing technology, an unprecedented number of SARSCoV-2 genomic sequences have garnered. This plethora of data has allowed, for the first time, in-depth microevolutionary analyses and monitoring of the emergence, spread, and adaptations of new lineages/strains during the course of an epidemic or pandemic [76-80]. Molecular clock analyses suggest that SARS-CoV-2, within the first year of the pandemic, displayed a slightly higher mutation rate than SARS-CoV-1, MERS-CoV, or HCoV-OC43. 
This is in agreement with a phenomenon termed time-dependent rate variation, where slightly deleterious mutations tend to be purged in the later stages of an epidemic [76,81]. However, SARS-CoV-2 did not appear to have undergone significant mutational changes within the first year of its spread in the human population [82], and this poses difficulties for phylogenetic analyses [83].

A very interesting study analyzed 192,000 SARS-CoV-2 genomes that were sequenced in the first year of the pandemic (as of December 2020) and focused on non-synonymous mutations, their distribution across the genome, and their functional/structural effects [84]. The study observed regions of low and high non-synonymous mutations, even within the same gene. Overall, ORF1ab was subject to lower mutation rates compared to the structural and accessory ORFs. The genome regions encoding for the nucleocapsid-structured regions/domains also had significantly reduced mutation rates. Reassuringly, these observed microevolutionary patterns of mutation rates for the various genomic regions of SARS-CoV-2 are in agreement with divergence at the macroevolutionary/genus level [52]. Furthermore, the authors of that study argue that the residues of the spike receptor-binding domain (RBD) that come into contact with ACE2 are under strong purifying selection [84]. Thus, the epitopes for these residues are "protected" from mutations, meaning that antibodies targeting such conserved epitopes are at a lower risk of immunological escape by the virus [84]. In conclusion, structural constraints (i.e., tightly packed cores and proteinprotein interaction surfaces) and genome organization (i.e., regions of overlapping ORFs) are drivers of purifying selection in SARS-CoV-2 [84]. Indeed, the programmed frameshift element and its related RNA secondary structure elements, situated at the overlap between ORF1a and ORF1b, are highly conserved [85].

Interestingly, another study observed the occurrence of recurrent missense mutations in certain regions of SARS-CoV-2, a sign of adaptation and convergent evolution [86]. An experimental evolution study of SARS-CoV-2 also confirmed the occurrence of several convergent mutations, especially at the Spike ORF [68].

\section{Evolution by Insertions/Deletions}

Apart from point mutations, insertions and deletions (indels) also occur frequently. Large-scale SARS-CoV-2 sequencing data (>1.7 million genomes) coupled with sophisticated bioinformatics analyses have revealed many such events, which are located more frequently at the $3^{\prime}$ half of the genome. These occur especially at the spike region and have the potential to lead to escape from neutralizing antibodies or even T-cell immunity [87]. For example, the Omicron variant has three deletions and one insertion within the spike and three deletions in other genomic regions. A non-coding deletion in the B.1.1.7 SARS-CoV-2 lineage increases the translational efficiency of the accessory ORF9b (an interferon antagonist); it interacts with other non-synonymous point mutations and increases viral transmissibility [88]. Spike-located inserts have also been associated with increased pathogenicity [89]. A notable example is the polybasic 4-amino-acid insertion of an initially suboptimal furin cleavage site (FCS) found in SARS-CoV-2 that plays a significant role in its transmission. This FCS has not yet been found in other sarbecoviruses, but it is present in other Beta-CoV subgenera [4,5,90,91]. One hypothesis about the origin of the FCS is that it was generated naturally by a template switch, followed by substitutions that eventually erased its similarity to the original sequence [87]. The FCS sequences of several CoVs resemble polybasic low-complexity regions that tend to evolve fast [92]. Notably, the Omicron variant bears two mutations (i.e., $\mathrm{N} 679 \mathrm{~K}$ and $\mathrm{P} 681 \mathrm{H}$ ) at the FCS. Alternative theories about the natural emergence of the FCS in SARS-CoV-2, perhaps involving recombination events with as yet unknown FCS-bearing sarbecoviruses or even with other Beta-CoV subgenera that cannot be excluded [52]. 


\section{The Progenitor of SARS-CoV-2 Was Already a Generalist Virus That Did Not Need Many Mutations to Adapt to Its Human Hosts}

Evolutionary and experimental studies show that the bat SARS-CoV-2 progenitor had already evolved into a generalist virus that had the ability to efficiently spread to other mammals. This is probably the reason that the virus did not undergo very strong positive selection during the first year of the pandemic [82]. Interestingly, a study that used surrogate entry assays and live virus showed that the SARS-CoV-2 spike protein has a broad host tropism for many mammalian ACE2 receptors (especially for those of cattle, cats, and dogs), whereas its tropism is significantly reduced for bat and bird ACE2 receptors [93]. Therefore, an intermediate host/reservoir is likely to have been required to allow sufficient point mutations and or insertions/deletions to occur in order to shift receptor usage from bats to humans. On the contrary, another very recent study identified the closest (so far) relative of SARS-CoV-2 in Rhinolophus bats from Laos [46]. The RBD of this Rhinolophus spike is very similar to the SARS-CoV-2 spike and is capable of binding to the human ACE2 receptor with an affinity that is similar to that of the original Wuhan strain. However, the isolate from Laotian bats lacks the FCS. Other Sarbecovirus spike proteins from bats have also demonstrated a capacity to bind to the human ACE2 receptor, and their carrier CoVs have been shown to be able to infect a wide range of cell lines including human airway cells $[44,94]$. A recent in vitro study revealed that the Omicron spike has, for the first time, acquired binding to mouse ACE2 [26], confirming the remarkable evolutionary plasticity of this region.

\section{Evolution by Recombination}

Although CoVs have a relatively low mutation rate compared to other RNA viruses, they also display a relatively high recombination rate [95]. The NSP s14 exonuclease is responsible for proof-reading and, thereby, the fidelity of genome replication. However, this enzyme also mediates recombination, whereas its inactivation decreases the frequency and also alters the patterns of recombination [65]. CoVs, like many other RNA viruses, tend to recombine frequently, using a template switching mechanism [96-99]. In addition, $\mathrm{CoV}$ transcription involves sub-genomic mRNAs that are formed by template switching among the transcriptional regulatory sequences (TRS) of the various ORFs (designated TRS-B: B for body) and the TRS at the 5'UTR (designated TRS-L: L for leader) [100,101]. Therefore, CoVs are inherently prone to recombination due to the fact of this characteristic transcription mechanism [102].

Many studies have highlighted the crucial role of homologous recombination in the evolution of CoVs, and these were extensively reviewed before the COVID-19 pandemic [97,103]. However, the plethora of new data and evolutionary/genomic analyses published in the last two years has significantly increased our understanding of the recombination events between both closely and distantly related CoVs. These recombination events may occur among members of the same strain/species, among members of the same subgenus, or even among members of different subgenera of the same genus. Furthermore, non-homologous recombination may occur even among CoVs and other viruses or even hosts. Recombination events, especially in certain regions such as spike, may result in changes in cell tropism and host range [44,59], with particular examples concerning MHV [55], TGEV [56], IBV [57], and FCoV/CCoV [38,58].

\section{Evolution by Intratypic Homologous Recombination}

Recombination among closely related strains/genotypes and species of the same subgenus occurs readily due to the high sequence identity throughout the genome and may result in the emergence of new strains [76,95,98,103-111]. We use the term intratypic to describe this category of recombination. Early analyses determined that in mammalian cells, recombination frequently occurs among regions that share identical stretches of $\sim 200$ base pairs and, furthermore, that recombination could occur at very low frequency between regions of sequence identity as small as 14 base pairs [112]. More specifically, CoVs have an intrinsically high intratypic recombination rate of approximately $25 \%$ across the genome. 
The crossover sites may occur anywhere, but selection pressure can lead them to cluster in certain hotspots $[99,113]$.

Several recent computational studies have analyzed available genomes from most $\mathrm{CoV}$ subgenera in order to better understand the patterns of intratypic recombination [76, $95,107,108,111,114,115]$. In one recent study [108], phylogenetic analyses of the various genomic regions revealed many incongruities among genomes of the same subgenus. These data were further analyzed with recombination detection program 4 (RDP4) and revealed 973 intratypic recombination events within 16 different subgenera [108]. Although these intratypic crossovers were scattered throughout the genome, and many of them were localized in hotspots that were, in turn, situated in the neighborhood of TRSs, especially preceding the Spike ORF. This region has long been considered as a modular recombination hotspot [42,52].

Evolutionary analyses of Sarbecovirus genomes, using the RDP5 and GARD (genetic algorithm for recombination detection) programs, identified many intratypic recombination events with a hotspot upstream of the Spike ORF and two cold spots in S1 and ORF8 [111]. This pattern may be attributed to antigenic selection in ancestral viruses, since the immunodominant $\mathrm{N}$-terminal domain and receptor-binding motif regions are within the S1 subunit. Another recent analysis focused on sarbecoviruses, embecoviruses, and SADS-CoV lineages and identified many recombination events within each lineage where the donor was unknown [95]. This is a clear indication that the sequence analysis of currently available samples has underestimated $\mathrm{CoV}$ diversity. In addition, that study also revealed that many of the intratypic recombination events occur within and around the Spike ORF.

One challenge when analyzing very similar genomes is how to distinguish recombination from undetected fast evolution, accompanied by positive selection, that leads to convergent mutations. Recombination events in three of the five Beta-CoV subgenera (e.g., sarbecoviruses, merbecoviruses, or embecoviruses) have been examined, with a particular focus on the $\mathrm{h} / \mathrm{m}$ ratio (homoplastic/non-homoplastic polymorphisms) [107]. This investigation determined that intratypic recombination events tend to localize around the spike region and account for $40 \%$ of the observed polymorphisms. Furthermore, the highest rates of intratypic recombination were found within embecoviruses in contrast to a similar study that found sarbecoviruses recombine with much higher frequency than any of the other two subgenera [115].

A survey (using RDP4) of $~ 158,000$ human CoV genomes (SARS-CoV-1, SARS-CoV-2, MERS-CoV, HCoV-OC43, HCoV-HKU1, HCoV-NL63, and HCoV-229E) that looked for signs of intratypic recombination [114] identified several high-confidence events in various human CoVs. Only eight recombination events of moderate confidence were identified among $\sim 157,000$ SARS-CoV-2 genomes. The majority of these events were located in the structural genes. It was also estimated that the time of emergence of each of the currently circulating human CoVs was within the last 70 years and, especially, for $\mathrm{HCoV}-229 \mathrm{E}$, continuous lineage replacements were observed.

Recombination events among currently circulating SARS-CoV-2 genomes should also occur. However, it would be expected [116] that such events would be difficult to detect at the start of the pandemic due to the high level of sequence identity among the circulating genomes. But as the pandemic progressed and more divergent SARSCoV-2 strains were circulating, it should become more possible to detect intra-SARSCoV-2 recombination events [117]. Indeed, several studies have already reported such events [114,117-120]. An analysis of 1.6 million SARS-CoV-2 genomes showed that $2.7 \%$ of circulating sequences belong to a recombinant lineage and that the recombination breakpoints occur disproportionately at the spike region [119]. As more point mutations occur in the various SARS-CoV-2 variants, there is the possibility of an even greater increase in the diversity of this species via intratypic recombinational shuffling. Therefore, SARSCoV-2 may still be within the first phase of a rather slow evolution that is mostly driven by point mutations and insertions/deletions. This may be followed by another phase of 
rapid divergence driven by a combination of point mutations/insertions/deletions and recombinational shuffling among the different lineages with significant implications for vaccine efficacies.

A question of great importance concerning the current SARS-CoV-2 pandemic is how it emerged, and whether a recombination event involving a bat Sarbecovirus resulted in its evolved ability to efficiently infect humans and other mammals. Studies conducted during the first phase of the pandemic suggested that SARS-CoV-2 is the product of recombination, where a close relative of a bat SARS-related genome (RaTG13) acquired the receptor-binding motif of the Spike gene of a pangolin SARS-related virus [36,121]. However, subsequent analyses suggested that no recent recombination event led to the emergence of SARSCoV-2 [76,122]. Instead, its bat ancestor already had evolved the necessary amino acids in the RBD that allowed it to act as a generalist and infect many other mammalian cells via the ACE2 receptor [76]. Similarly, another study [123] applied ancestral sequence reconstruction and structural modeling and concluded that an old recombination event occurred several decades ago at a common ancestor of SARS-CoV-1 and SARS-CoV-2 that led to the emergence of an RBD with an increased binding affinity for human ACE2. Thus, that ancestral Sarbecovirus and its descendants already had the ability to infect humans. All the above conclusions are further supported by the detection, in what is the closest progenitor to SARS-CoV-2 so far recognized, of Rhinolophus sp. found in Laos. Intriguingly, its spike is capable of binding with high affinity to human ACE2, but it lacks the FCS [46].

Recombination between members of the SARS-CoV-1 and SARS-CoV-2 lineages within the sarbecoviruses has also been observed [52,76,111]. This is a matter of great concern, since it demonstrates a potential for the future emergence of a SARS-CoV-3 that may combine the high pathogenicity of SARS-CoV-1 with the high infectivity of SARS-CoV-2.

\section{Evolution by Intertypic Homologous Recombination}

Homologous recombination among more distantly related CoVs from different subgenera is expected to occur infrequently, since their genomes share less than $50 \%$ nucleotide identity [108]. In addition, due to the fact of this low sequence identity and the undersampled CoV diversity, it will be difficult for many recombination software packages to detect old recombination events among different subgenera or even recent events involving as yet unsequenced subgenera, because the closest available relative of the unsequenced donor will still be quite divergent. Phylogenetic incongruence is a popular and robust method for such types of analyses [124]. Nevertheless, recombination among different CoV subgenera does happen, and we call such events intertypic. The most recent and striking example involves the emergence of swine enteric coronavirus due to the cassette-like recombination of the spike region between PEDV and TGEV, which belong to two different subgenera (i.e., Pedacovirus and Tegacovirus) of Alpha-genus CoVs [125].

Intertypic recombination between $\mathrm{CoVs}$ is possible due to the presence of the highly conserved transcriptional regulatory sequences (TRS) at the beginning of the various ORFs [100-102,125,126]. The main role of these TRSs is to facilitate template switching during transcription to generate sub-genomic (sg) RNAs [100,101]. In addition, these highly conserved TRSs could potentially function as recombination hotspots among distantly related strains/species [102]. At the same time, they may also function as barriers to recombination between lineages that possess very different TRSs [127]. Based on these hypotheses, there have been studies to engineer live attenuated CoVs with altered TRSs that will not be able to recombine with other CoVs and, thus, block reversion and vaccinederived epidemics [102]. Cases of live attenuated vaccine strains that reverted to pathogenic ones via recombination with wild-type close relatives have been observed for poliovirus vaccines [128-133].

The most extensive large-scale analysis of intertypic recombination undertaken so far included 196 representative genomes from all fully sequenced CoV subgenera [52]. This analysis was based on the phylogenetic incongruence of 15 NSPs of ORF1ab (NSP 11 was excluded due to the fact of its short length) and the other four core ORFs (i.e., 
spike, envelope, membrane, and nucleocapsid). The analysis identified several phylogenetic incongruities supported by neighbor joining, PhyML, Bayesian trees, and by the Shimodaira-Hasegawa test. The observed incongruities were consistent with old as well as recent recombination events that occurred at the origin of certain subgenera or even later. The vast majority of these events were detected at the spike region, highlighting it as a recombination hotspot even among different subgenera. These spike-localized recombination events were observed in five Alpha-CoV subgenera, one Gamma-CoV subgenus, and all three Delta-CoV subgenera. Furthermore, several donors of intertypic events in Gamma and Delta genus CoVs most probably involve subgenera that have yet to be sequenced. This is in agreement with another recent observation that the currently known $\mathrm{CoV}$ diversity is only an underestimate and that many more lineages wait to be discovered [95].

Intriguingly, no well-supported intertypic recombination event of the spike region was observed among any of the five Beta-CoV subgenera [52], but there was an incongruence concerning the nucleocapsid region of merbecoviruses. The same lack of intertypic recombination among Beta-CoV subgenera was also reported in $[107,108]$. This observation is of great importance because, so far, it does not appear that SARS-CoV-2 is able to recombine with any of the other circulating human CoVs that belong to different subgenera and genera. MERS-CoV is a Beta-CoV Merbecovirus, HCoV-HKU1 and HCoV-OC43 are Beta-CoV embecoviruses, and HCoV-NL63 and HCoV-229E are Alpha-genus CoVs. However, a recent theoretical analysis based on syntenic homologous regions has shown that there exist potential recombination crossover sites approximately $30-40$ nucleotides long with very high sequence identity between the SARS-CoV-2 genome and that of its closest circulating human CoV, MERS-CoV; these are situated in ORF1b and the spike $\mathrm{S} 2$ region [126]. It may be proposed that intertypic recombination events between these two viruses could occur in the gastrointestinal tract, where both receptors (i.e., ACE2 for SARS-CoV-2 and dipeptidyl peptidase-4 (DPP4) for MERS-CoV) are highly co-expressed. In such an evolutionary scenario, the intertypic recombinant could possibly change its tissue tropism and/or pathogenicity by undergoing further adaptive evolution. This might render the ongoing vaccination programs obsolete due to the fact of their focus on certain genomic regions and, especially, the spike ORF, which tends to evolve rapidly (both by point mutations and recombination). These observations [126], together with the evidence presented in [52] for the high intertypic recombination potential in other $\mathrm{CoV}$ genera, are a significant cause for concern and vigilance.

\section{Intertypic Recombination Is Modular}

Another important observation in [52] was that the intertypic recombination events did not occur as single crossovers but instead occurred as double crossovers, meaning that a sequence module or cassette was exchanged. Our interpretation is that several genomic features prevent (or select against) the occurrence of such intertypic single crossover events: (i) the long-range genetic/physical interactions within certain elements of a $\mathrm{CoV}$ genome and (ii) the distinct accessory ORF architectures of the various subgenera (especially in Beta-genus CoVs).

Reverse genetic experiments have shown that the $\mathrm{N}$ protein, encoded by an ORF at the $3^{\prime}$ of the genome, is essential for replication and have also demonstrated that, while $\mathrm{N}$ proteins from different members of the same genus may be at least partially compatible, those from different genera are functionally incompatible [134,135]. One such example is PEDV-N against TGEV-N and PDCoV-N proteins [135]. In addition, $\mathrm{N}$ proteins from other genera may even have a suppressive effect, which has serious implications for $\mathrm{CoV}$ coinfection from different genera [135]. The $\mathrm{N}$ protein may also be involved in circularization of the genome by acting as a bridge between the $5^{\prime}$ and $3^{\prime}$ ends [136]. Furthermore, RNA secondary structures have been shown to form long-range interactions within the genome [137] and to interact not only with viral but also cellular components in order to initiate transcription and replication [138]. Genetic interactions have been observed between the non-structural peptides NSP 8, NSP 9 (encoded at the end of ORF1a), and 
the pseudoknot at the $3^{\prime}$ end of the genome [139]. Recently, a protein interaction map was generated for SARS-CoV-1, SARS-CoV-2, and MERS-CoV peptides based on affinity purification/mass spectrometry in HEK-293T/17 cells, and it revealed 366, 389, and 296 protein interactions with human proteins [140]. Only $21 \%$ of the interactions were shared by all three viruses, $45 \%$ of interactions were unique for each virus, whereas SARS-CoV-2 and MERS-CoV shared only $24 \%$ of interactions. Accordingly, a single crossover intertypic recombinant between SARS-CoV-2 and MERS-CoV would most probably be inviable, partly due to the protein-protein interaction incompatibilities. Thus, single crossover recombination events among different subgenera may break/disrupt such genetic or even physical interactions, whereas double-crossover/cassette-like events are likely to retain compatible interactions.

\section{Evolution by Non-Homologous Recombination among CoVs and with Other Taxa}

Apart from homologous intratypic and intertypic recombination events, non-homologous recombinations also occur in $\mathrm{CoVs}$, leading to the acquisition of accessory genomic regions by gene duplication or from other CoVs, viruses, and even hosts [52,63]. A recent evolutionary study developed PSI-Blast profiles for 73 non-redundant CoV accessory ORF families (AOFs), permitting the performance of a very sensitive homology search [52]. The study observed that many of these AOF families had homologs found only in certain CoV subgenera or genera. Each genus and, in certain cases, some subgenera (especially in the Beta-genus CoVs) had very distinct accessory ORF architectures $[52,63,141]$. Such a pattern could be explained by either the "birth" of genes de novo in the common ancestor of certain genera/subgenera, the rapid divergence of existing ORFs and loss of the homology signal, or via non-homologous recombination with ORFs (followed by rapid divergence) from other CoVs, viruses, or even hosts [52,142-145].

Evolutionary studies have identified several non-homologous recombination events in CoVs involving gene duplications. Such events include a bat Beta-CoV Hibecovirus ORF2 and a Luchacovirus ORF6, originating from spike [52]. Another gene duplication event concerns the ORF3a of Beta-CoV Sarbecovirus/Hibecovirus/Nobecovirus that appears to have originated from the core membrane ORF (followed by rapid divergence) $[52,144]$ or SARS-CoV-2 ORF8 originating from ORF7a [145].

The study presented in [52] found evidence (and also confirmed previous observations) of horizontal gene transfer for seven AOFs that had homologs in other taxa, outside of the CoVs; three of them were localized in the vicinity of spike. The best studied, striking, and rather worrying example concerns a hemagglutinin-esterase found in Beta-CoV embecoviruses, situated just before the spike region. This gene was transferred from an influenza $\mathrm{C} / \mathrm{D}$ virus, either directly or via a Torovirus that then adapted and co-evolved with the spike [146-149]. Other examples include genes for a phosphodiesterase (probably originating from toroviruses) [52], a C-type lectin (probably originating from mammals) [150], a p10-like gene (probably originating from reoviruses) [151], an NSP-1-like gene (probably originating from avian rotavirus-g), a uridine kinase (originating from a whale host) [152], and a distant homolog to the capsid protein of human astrovirus 5. Therefore, toroviruses emerge as a key taxon, not only because they belong to the same order (i.e., Nidovirales) as CoVs, but also because they can act as gene donors in other viral orders as well, e.g., porcine enterovirus-G $[153,154]$. Given the worldwide distribution and high infection rate of toroviruses [153], many more non-homologous recombination events between them and their close relatives, the CoVs, may be detected in the near or more distant future.

\section{Implications for Vaccine Design and Development}

As of Autumn 2021, more than twenty COVID-19 vaccines have received emergency use authorization in at least one country, with efficacies in the range of 66-95\% [155]. These vaccines are grouped into two major categories: the ones based on the inactivated virus and the ones that are based on the spike DNA/mRNA or spike protein $[156,157]$. Vaccines in former category should train the immune system with many diverse SARS-CoV- 
2 epitopes; however, virus aggregate formation or protein denaturation/degradation or crosslinking during the inactivation process may significantly reduce their efficacy [158]. So far, vaccines in the latter category demonstrate higher efficacies [155]. At the same time, the spike-focused vaccines are vulnerable to mutations in a region of known genetic instability. Such mutations have previously led to the emergence of VoCs that are already capable of partly evading the immunity conferred by current vaccines and, over time, may render these vaccines ineffective [159-163]. Worryingly, the recent emergence of the Omicron (B.1.1.529) VoC, which has an unusually high number of mutations located in the spike region, raises great concern regarding the efficacies of current vaccines against this VoC. Epidemiological surveillance data from South Africa and the UK already show an increased risk of reinfection by Omicron $[25,164]$. Most mAbs that target antigenic sites at the highly mutated RBM are already unable to neutralize the Omicron VoC in vitro [26]. The problem may soon be exacerbated by intratypic or even intertypic recombination events in the spike region that could lead to further diversity $[52,95,107,108,111]$. On the other hand, the fast development (within a few months) of new vaccines based on current mRNA vaccine platforms allows for an unprecedented rapid and effective response to new variants.

To address this looming problem, the National Institute of Allergy and Infectious Diseases (NIAID) in the USA has recently awarded three projects for the development of pan-coronavirus vaccines that will provide broad protective immunity to multiple CoVs. All three projects focus on the spike protein but specifically on conserved regions that may cover all sarbecoviruses or even all Beta-genus CoVs. Furthermore, such vaccines would be an insurance against any future intertypic recombination events where a highly contagious SARS-CoV-2 variant acts as a spike donor to a human or animal CoV of the same or different subgenus, thus transforming it into a highly contagious human pathogen. The spike vaccine approach that is targeting more CoV taxa is promising as several studies have already shown [165-168]. For example, pan-Sarbecovirus neutralizing antibodies have been observed in people that were originally infected by SARS-CoV-1 in the 2002-2003 epidemic and were later immunized with the BNT162b2 mRNA vaccine that targets the SARS-CoV-2 spike [167]. In addition, an immunodominant region located at the C-terminal fusion peptide domain of the SARS-CoV-2 spike can be recognized by CD4 ${ }^{+} \mathrm{T}$ cells that are generated by other common cold human CoVs [168]. Interestingly, some mAbs that target antigenic sites outside the RBM are capable of neutralizing even the highly mutated Omicron VoC in vitro [26].

The spike protein, especially its RBD, is a favored vaccine target, because it is capable of generating both a strong B-cell and T-cell response [169,170]. However, other protein (e.g., the nucleocapsid) are also capable of generating a robust T-cell response [171]. Moreover, the nucleocapsid gene displays rapid and high expression, high sequence conservation, and a low propensity for recombination $[52,84,172]$. On the other hand, early work on SARSCoV-1 demonstrated that vaccines based on the nucleocapsid were ineffective and also enhanced the immunopathology in the lungs of senescent mice upon viral challenge [169]. Nevertheless, the SARS-CoV-2 nucleocapsid is already being tested as a vaccine target on its own, or in combination with the spike, or even with a third ORF as well [173-178]. Three such candidate vaccines (one in the USA and two in the European Union) have already reached Phase 2 clinical trials as of November 2021 [156].

A study of healthcare workers has also shown that pre-existing $\mathrm{T}$ cells against the early-transcribed replication transcription complex (RTC) of other human CoVs rapidly expand upon SARS-CoV-2 exposure, leading to an abortive infection [179]. Thus, vaccines against the highly conserved RTC may be capable of covering a broad spectrum of CoVs. Genes encoding components of the RTC are highly conserved and have a low propensity for recombination among the various CoVs [52]. In our opinion, future effective vaccines will target more than one region that contains conserved epitopes. The unexpectedly high number of mutations at the spike of the Omicron VoC also supports the strategy of investigating regions other than spike as vaccine targets. 


\section{Implications for Drug Design and Development}

Projects to develop new drugs or repurpose existing ones have identified many candidates for the treatment of COVID-19 [180]. As of November 2021, two drugs have obtained government approval-Remdesivir and Molnupiravir [181] — whereas, a third candidate drug (i.e., Paxlovid) is also expected to obtain approval soon. Remdesivir is a ribonucleotide analogue that inhibits the RdRp and causes termination of viral replication [182]. Molnupiravir is a ribonucleoside analogue that introduces copying errors and, thus, dramatically increases the mutation rate of many diverse CoVs [71,72]. Paxlovid is a SARS-CoV-2 specific 3CL protease inhibitor that binds at the enzyme's catalytic site. Mutations could arise that render any of these drugs ineffective, as has happened for human immunodeficiency viruses (HIV). For example, protease inhibitor monotherapy with ritonavir in HIV-positive patients led to the emergence of drug-resistant mutations (of the viral protease) that appeared in an ordered, stepwise fashion [183]. However, unlike HIV, SARS-CoV-2 infections are not chronic, and given the relatively low mutation rate, the drug-resistant mutants would not easily emerge within the patient. In addition, any drug-resistant mutants would also need to retain a fitness that is similar to that of wild-type strains in order not to be outcompeted. Remdesivir-resistant mutants have been circulating with a very low frequency in the general population; in vitro, they have emerged after several serial passages and display reduced fitness [182]. For all that, we would suggest that it might be wise to exclude viral proteins that are key drug targets from the list of targets for new vaccines. This is because antiviral drugs, in contrast to vaccines, will only be used on a minority of patients, and the inclusion of their target proteins in vaccine preparations will introduce considerable selection for the mutation of the viral genes that encode them.

\section{Five Scenarios for the Future Evolution of SARS-CoV-2 during the COVID-19 Pandemic}

Based on the observed data and evolutionary analyses for all CoVs so far, and especially the wealth of data generated in the last two years for SARS-CoV-2, we envisage several scenarios (some of high concern) for the evolution of SARS-CoV-2 during the current COVID-19 pandemic (see Figure 1). These scenarios could also be applicable to any future epidemic involving a novel $\mathrm{CoV}$.

\subsection{Scenario 1: Structural Constraints Limit Any Further Evolution of the SARS-CoV-2 Spike}

In this scenario (Figure 1A), structural constraints [84] should not permit any further major mutations in the spike region that make the virus more infectious or significantly change the epitopes that are targeted by the current vaccines. Accordingly, as more people acquire immunity either via natural infection or spike-targeted vaccination, the COVID-19 pandemic will be controlled. The observed waning neutralizing antibody response generated by current vaccination schemes will make necessary a third or even regular booster doses, but some level of protection should continue to exist in vaccinated and previously infected people. In the longer term, immunization and/or protection by natural infection together with available drugs would lead to the transition of the pandemic into a seasonal (low-mortality) epidemic, similar to influenza. A protective effect against SARS-CoV-2 has been observed by cross-reactive $\mathrm{CD} 4^{+} \mathrm{T}$ cells that recognize the $\mathrm{C}$-terminal section of spike and were elicited by other common cold CoVs [168]. The effective deployment of antiviral drugs, such as Molnupiravir, which recently gained approval in the UK, is also likely to promote the transition of the COVID-19 pandemic into a seasonal epidemic. The impact of long-COVID syndrome should also be seriously considered [184,185]. However, the recent emergence of the highly infectious Omicron VoC, with more than 30 new mutations in the spike ORF, demonstrates that the evolutionary flexibility of this region is significantly greater than was originally believed. Therefore, Scenario 1 may not be as feasible as it appeared before the emergence of Omicron. If Omicron or any future variant is more trans- 
missible and significantly less pathogenic, then natural infections together with available drugs might lead to herd immunity and to the end of the pandemic.

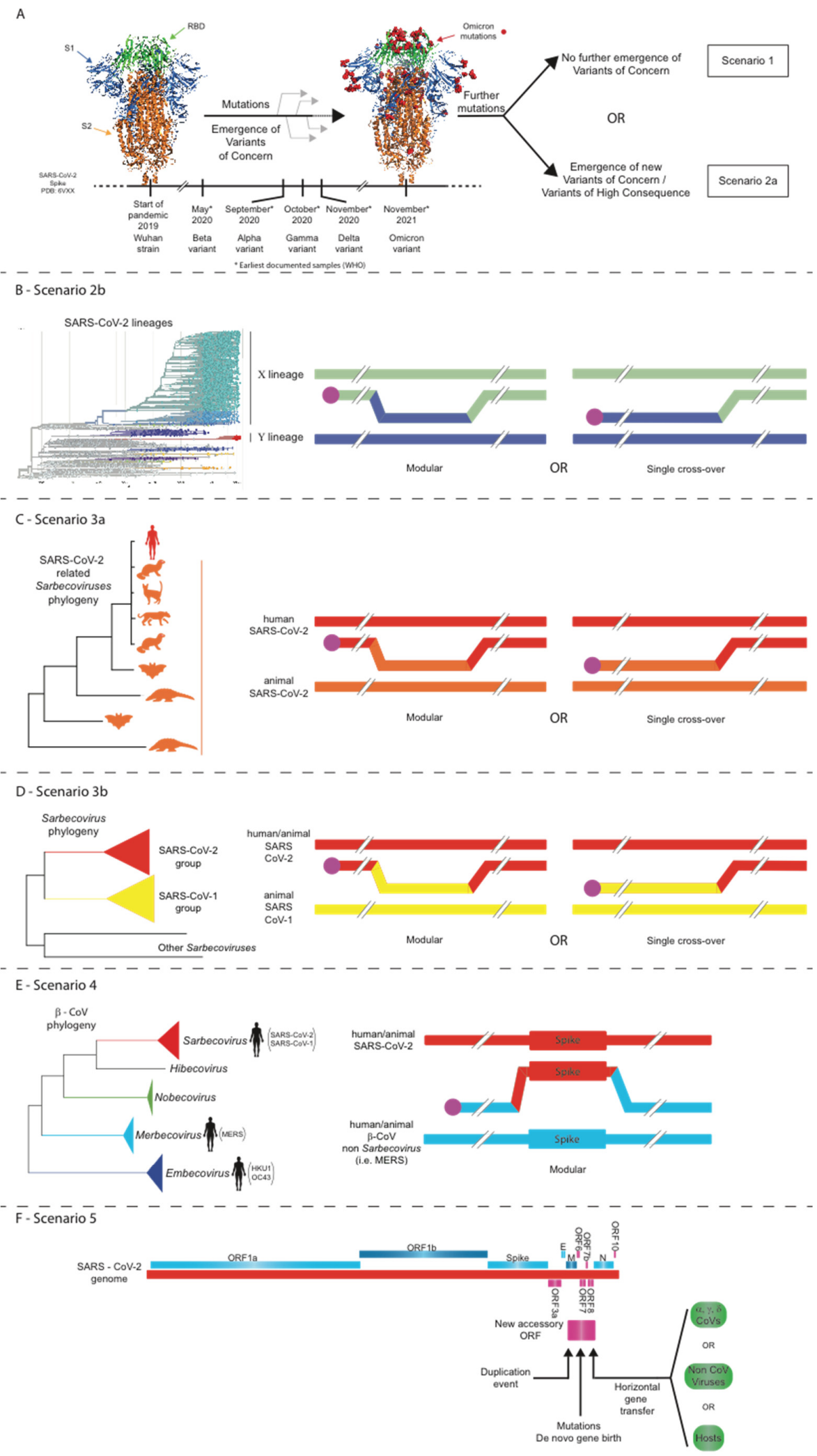

Figure 1. Five scenarios for the future evolutionary trajectory of SARS-CoV-2. (A) Scenario 1: structural constraints limit any further evolution of the SARS-CoV-2 spike; Scenario 2a: point mutations, 
insertions/deletions, and/or intra-SARS-CoV-2 recombination events lead to the evolution of novel SARS-CoV-2 strains. (B) Scenario 2b: intra-SARS-CoV-2 recombination events lead to the evolution of novel SARS-CoV-2 strains. (C) Scenario 3a: intratypic recombinations between SARS-CoV-2 and closely related sarbecoviruses. (D) Scenario 3b: intratypic recombinations between SARS-CoV-2 and other related sarbecoviruses. (E) Scenario 4: intertypic recombination between SARS-CoV-2 and viruses from other Beta-CoV subgenera. (F) Scenario 5: non-homologous recombination of SARS-CoV-2 with other coronaviruses or even other viruses/hosts.

16.2. Scenario 2: Point Mutations, Insertions/Deletions, and/or Intra-SARS-CoV-2 Recombination Events Lead to the Evolution of Novel SARS-CoV-2 Strains

In this scenario, many more people continue to become infected, especially in the developing world, where vaccination rates remain very low. Thus, the emergence of a new SARS-CoV-2 strain that is highly divergent and more transmissible and/or more virulent and/or capable of escaping the protection conferred by current vaccines and/or drugs becomes ever more probable with every new infection. Such variants might arise either via point mutations and/or insertions/deletions and/or recombination with other circulating SARS-CoV-2 lineages (Figure 1A,B) [75]. The emergence of the highly infectious Alpha, followed by a more infectious Delta, and now by an even more infectious Omicron variant is not simply the addition of a single amino-acid change, but several other correlated mutations also need to occur to maintain the structural integrity of the virus (including that of its genome) or to increase the expression of interferon antagonist accessory ORFs [25,87,88,91,186-188]. Furthermore, it is conceivable that a Delta-Omicron recombinant arises within the next few months, during which both variants will be circulating. Even before the emergence of Omicron, experts in the field, vaccine developers, and policymakers were already preparing contingency plans for the possible emergence of a vaccine-escape and/or more lethal variants. The relatively high mutation rate of the Spike gene [68] and the observation of insertions within the (computationally predicted) epitopes of spike [87] also favor this scenario. In addition, 3D structural simulations of spike-trimer single and double mutants at the RBD show that several mutations may give rise to even more stable structures [189]. Deep mutational scanning of the SARS-CoV-2 spike RBD revealed that, although many mutations are deleterious, a considerable number of them are either well tolerated or actually enhance binding to the ACE2 receptor [190]. The emergence of the A.30 variant and its cell entry properties [191] shows that new strains may not only evade current spike-targeted vaccines but also evolve a preference for other cell types that would promote extrapulmonary spread. Worryingly, new reservoirs of SARS-CoV-2 could be established in farmed or wild animals (including rodents [26]) and lead to the emergence of new strains with properties that would allow spill-back to humans as studies in minks have already shown $[49,50]$.

\subsection{Scenario 3: Intratypic Recombinations between SARS-CoV-2 and Other Sarbecoviruses}

In a third less probable but still feasible scenario (Figure 1C), a SARS-CoV-2-infected person could pass the virus to an animal infected with another closely related CoV from the SARS-CoV-2 lineage, and the two viruses then recombine. By these means, an even more divergent SARS-CoV-2 strain could emerge that escapes protection elicited by current vaccines. In a variation of this scenario (Figure 1D), a SARS-CoV-2-infected person passes the virus to an animal infected with another closely related CoV from the SARS-CoV-1 lineage and the two viruses recombine. In this case, given the modular recombination potential of the spike region, a new Sarbecovirus may emerge that combines the high infectivity of SARS-CoV-2 (by acting as donor of, for example, the Omicron spike) with the high mortality rates $(\sim 10 \%)$ of SARS-CoV-1 infections. Alternatively, an accessory ORF from the SARS-CoV-1 lineage replaces via homologous recombination its ortholog in SARSCoV-2, and the recombinant virus displays altered properties. Accessory ORF orthologs among different sarbecoviruses (i.e., ORF3a of SARS-CoV-1 and SARS-CoV-2) have been shown to use different strategies to induce apoptosis [61] with important implications for 
the asymptomatic spread of the virus. The feasibility of this scenario is evidenced by recent analyses of the role of recombination in Sarbecovirus evolution [52,76,111].

\subsection{Scenario 4: Intertypic Recombination between SARS-CoV-2 and Viruses from Other} Beta-CoV Subgenera

The spike region of a highly infectious SARS-CoV-2 passes (via modular intertypic recombination) to an animal or human $\mathrm{CoV}$ of another subgenus within the Beta-genus CoVs (Figure 1E) and undergoes rapid divergence due to the fact of adaptation. This might happen with a MERS or MERS-like virus obtaining the highly infectious SARS-CoV-2 spike. MERS-CoV has low infectivity but very high mortality $(\sim 30 \%)$. A recombinant of this type would be catastrophic unless rapid vaccine development and distribution occurs across the entire world. Another variation of this scenario is for an as yet undiscovered Beta-CoV subgenus to recombine with SARS-CoV-2. Although improbable, this scenario is not infeasible as bioinformatics analyses have shown [52,126], and this emphasizes the need to develop pan-coronavirus vaccines.

16.5. Scenario 5: Accessory ORF Acquisition by Non-Homologous Recombination of SARS-CoV-2 with Other Coronaviruses or Even Other Viruses/Hosts or Even via De Novo Gene Birth

A SARS-CoV-2 genome acquires (via non-homologous recombination) accessory ORFs from gene duplication, (via horizontal gene transfer) from other CoVs, viruses, or hosts, or even by de novo gene birth; as a result, its molecular biology changes (Figure 1F). Examples of accessory ORF acquisition events by the above evolutionary processes have already been observed in Beta-genus CoVs [52,63,144,145,192,193]. It is not yet clear what would be the implications if an accessory ORF from the SARS-CoV-1 lineage were to be introduced via non-homologous recombination into SARS-CoV-2. Finally, there are no current data that support a scenario of a homologous recombination event between SARS-CoV-2 and CoVs from other genera [52].

\section{Conclusions-Implications for Vaccination Policies}

Several studies have shown that vaccination does protect people against infection in the short term and against severe disease and death in the long term [194]. It also lowers the chance of vaccinated people infecting other people, even if a breakthrough infection occurs [194]. In addition, simulations have shown that vaccination reduces the probability of the emergence of a vaccine-resistant strain, but only if transmission control measures are maintained throughout the vaccination campaign [195]. People in the developing world frequently come into contact with wild animals that are reservoirs for many CoVs; they also have significantly lower access to current vaccines [196]. The human-animal interface is a serious source of concern for spill-over events [197]. Furthermore, in some developing countries, the number of immunosuppressed patients (e.g., due to HIV) is very high. Prolonged viral replication occurs in immune-compromised/suppressed patients and can lead to the emergence of more infectious and even vaccine-evading variants of concern $[79,198]$. Thus, the vaccination policies of the developed world should include the timely distribution of effective vaccines in sufficient numbers to protect populations in the developing world. This would also act as an insurance against the manifestation of catastrophic scenarios concerning the future evolutionary path of SARS-CoV-2 or to ensure that no other $\mathrm{CoV}$ pandemics occur in the near or more distant future. In addition, the early detection of the Omicron VoC in Southern Africa, due to the fact of rigorous genomic screening, highlights the importance of developed countries supporting genome sequencing infrastructure in developing countries. In this new era of urbanization, global transport, intensive farming, and habitat destruction, close collaboration and support among all countries is imperative in the fight against this and any future pandemic. No matter what evolutionary trajectory SARS-CoV-2 follows, sociopolitical factors and international collaboration will determine the future path of the COVID-19 pandemic. 
Author Contributions: Conceptualization, G.D.A. and S.G.O.; writing-manuscript preparation, G.D.A., M.N., E.T., K.C., P.M. and S.G.O.; visualization, M.N. and G.D.A.; supervision, G.D.A. All authors have read and agreed to the published version of the manuscript.

Funding: M.N. thanks the Bodossakis Foundation (MSc studentship: BDA-394) and the University of Thessaly (Ph.D studentship: DEKA-UTH-259) for the financial support.

Institutional Review Board Statement: Not applicable.

Informed Consent Statement: Not applicable.

Data Availability Statement: Not applicable.

Conflicts of Interest: The authors declare no conflict of interest.

\section{Abbreviations}

\begin{tabular}{|c|c|}
\hline 3CLpro & 3-chymotrypsin-like protease \\
\hline ACE2 & angiotensin-converting enzyme 2 \\
\hline $\mathrm{AOF}$ & accessory ORF family \\
\hline $\mathrm{APN}$ & aminopeptidase $\mathrm{N}$ \\
\hline $\mathrm{CCoV}$ & canine coronavirus \\
\hline CDC & Centers for Disease Control and Prevention \\
\hline $\mathrm{CoV}$ & coronavirus \\
\hline COVID-19 & coronavirus disease 2019 \\
\hline DPP4 & dipeptidyl peptidase 4 \\
\hline FCoV & feline coronavirus \\
\hline FCS & furin cleavage site \\
\hline FIPV & feline infectious peritonitis virus \\
\hline GARD & genetic algorithm for recombination detection \\
\hline GISAID & Global Initiative on Sharing All Influenza Data \\
\hline HEL & NSP 13 C-terminal nucleoside triphosphate-binding/helicase motif \\
\hline HIV & human immunodeficiency virus \\
\hline IBV & infectious bronchitis virus \\
\hline mABs & monoclonal antibodies \\
\hline MERS & Middle East respiratory syndrome \\
\hline MHV & murine hepatitis virus \\
\hline $\mathrm{N}$ & nucleocapsid \\
\hline NiRAN & nidovirus RdRp-associated nucleotidyl transferase domain \\
\hline NSP & non-structural peptide \\
\hline nt & nucleotide \\
\hline ORF & open reading frame \\
\hline PDCoV & porcine delta coronavirus \\
\hline PEDV & porcine epidemic diarrhea virus \\
\hline RBD & receptor-binding domain \\
\hline RBM & receptor-binding motif within the RBD of spike \\
\hline RDP4 & recombination detection program 4 \\
\hline $\operatorname{RdRp}$ & RNA-dependent RNA polymerase \\
\hline SADS & swine acute diarrhea syndrome \\
\hline SARS-CoV-2 & severe acute respiratory syndrome coronavirus-2 \\
\hline TGEV & transmissible gastroenteritis virus \\
\hline TRS & transcriptional regulatory sequence \\
\hline UTR & untranslated region \\
\hline $\mathrm{VoC}$ & variant of concern \\
\hline WHO & World Health Organization \\
\hline ZBD & NSP 13 N-terminal cysteine-rich zinc-binding domain. \\
\hline
\end{tabular}




\section{References}

1. Zhou, P.; Yang, X.-L.; Wang, X.-G.; Hu, B.; Zhang, L.; Zhang, W.; Si, H.-R.; Zhu, Y.; Li, B.; Huang, C.-L.; et al. A Pneumonia Outbreak Associated with a New Coronavirus of Probable Bat Origin. Nature 2020, 579, 270-273. [CrossRef]

2. Wu, F.; Zhao, S.; Yu, B.; Chen, Y.-M.; Wang, W.; Song, Z.-G.; Hu, Y.; Tao, Z.-W.; Tian, J.-H.; Pei, Y.-Y.; et al. A New Coronavirus Associated with Human Respiratory Disease in China. Nature 2020, 579, 265-269. [CrossRef]

3. Gorbalenya, A.E.; Baker, S.C.; Baric, R.S.; de Groot, R.J.; Drosten, C.; Gulyaeva, A.A.; Haagmans, B.L.; Lauber, C.; Leontovich, A.M.; Neuman, B.W.; et al. The Species Severe Acute Respiratory Syndrome-Related Coronavirus: Classifying 2019-NCoV and Naming It SARS-CoV-2. Nat. Microbiol. 2020, 5, 536-544. [CrossRef]

4. Andersen, K.G.; Rambaut, A.; Lipkin, W.I.; Holmes, E.C.; Garry, R.F. The Proximal Origin of SARS-CoV-2. Nat. Med. 2020, 26, 450-452. [CrossRef]

5. Holmes, E.C.; Goldstein, S.A.; Rasmussen, A.L.; Robertson, D.L.; Crits-Christoph, A.; Wertheim, J.O.; Anthony, S.J.; Barclay, W.S.; Boni, M.F.; Doherty, P.C.; et al. The Origins of SARS-CoV-2: A Critical Review. Cell 2021, 184, 4848-4856. [CrossRef]

6. Woo, P.C.Y.; Wang, M.; Lau, S.K.P.; Xu, H.; Poon, R.W.S.; Guo, R.; Wong, B.H.L.; Gao, K.; Tsoi, H.-W.; Huang, Y.; et al. Comparative Analysis of Twelve Genomes of Three Novel Group 2c and Group 2d Coronaviruses Reveals Unique Group and Subgroup Features. J. Virol. 2007, 81, 1574-1585. [CrossRef]

7. Chen, Y.; Liu, Q.; Guo, D. Emerging Coronaviruses: Genome Structure, Replication, and Pathogenesis. J. Med. Virol. 2020, 92, 418-423. [CrossRef]

8. Rota, P.A.; Oberste, M.S.; Monroe, S.S.; Nix, W.A.; Campagnoli, R.; Icenogle, J.P.; Peñaranda, S.; Bankamp, B.; Maher, K.; Chen, M.-H.; et al. Characterization of a Novel Coronavirus Associated with Severe Acute Respiratory Syndrome. Science 2003, 300, 1394-1399. [CrossRef]

9. Bermingham, A.; Chand, M.A.; Brown, C.S.; Aarons, E.; Tong, C.; Langrish, C.; Hoschler, K.; Brown, K.; Galiano, M.; Myers, R.; et al. Severe Respiratory Illness Caused by a Novel Coronavirus, in a Patient Transferred to the United Kingdom from the Middle East, September 2012. Euro Surveill. 2012, 17, 20290. [CrossRef]

10. Pascual-Iglesias, A.; Sanchez, C.M.; Penzes, Z.; Sola, I.; Enjuanes, L.; Zuñiga, S. Recombinant Chimeric Transmissible Gastroenteritis Virus (TGEV)—Porcine Epidemic Diarrhea Virus (PEDV) Virus Provides Protection against Virulent PEDV. Viruses 2019, 11, 682. [CrossRef]

11. Weiss, S.R.; Navas-Martin, S. Coronavirus Pathogenesis and the Emerging Pathogen Severe Acute Respiratory Syndrome Coronavirus. Microbiol. Mol. Biol. Rev. 2005, 69, 635-664. [CrossRef]

12. Gorbalenya, A.E.; Enjuanes, L.; Ziebuhr, J.; Snijder, E.J. Nidovirales: Evolving the Largest RNA Virus Genome. Virus Res. 2006, 117, 17-37. [CrossRef]

13. Saberi, A.; Gulyaeva, A.A.; Brubacher, J.L.; Newmark, P.A.; Gorbalenya, A.E. A Planarian Nidovirus Expands the Limits of RNA Genome Size. PLoS Pathog. 2018, 14, e1007314. [CrossRef]

14. Gulyaeva, A.A.; Gorbalenya, A.E. A Nidovirus Perspective on SARS-CoV-2. Biochem. Biophys. Res. Commun. 2021, 538, 24-34. [CrossRef]

15. ICTV Coronaviridae Study Group International Committee on Taxonomy of Viruses (ICTV). Available online: https://talk ictvonline.org/ictv-reports/ictv_9th_report/positive-sense-rna-viruses-2011/w/posrna_viruses/223/coronaviridae-figures (accessed on 17 September 2020).

16. Holmes, K.V. Coronaviruses (Coronaviridae). Encycl. Virol. 1999, 291-298. [CrossRef]

17. Lauber, C.; Ziebuhr, J.; Junglen, S.; Drosten, C.; Zirkel, F.; Nga, P.T.; Morita, K.; Snijder, E.J.; Gorbalenya, A.E. Mesoniviridae: A Proposed New Family in the Order Nidovirales Formed by a Single Species of Mosquito-Borne Viruses. Arch. Virol. 2012, 157, 1623-1628. [CrossRef]

18. Lauber, C.; Gorbalenya, A.E. Partitioning the Genetic Diversity of a Virus Family: Approach and Evaluation through a Case Study of Picornaviruses. J. Virol. 2012, 86, 3890-3904. [CrossRef]

19. Shu, Y.; McCauley, J. GISAID: Global Initiative on Sharing All Influenza Data-From Vision to Reality. Euro Surveill. 2017, 22, 30494. [CrossRef]

20. Hadfield, J.; Megill, C.; Bell, S.M.; Huddleston, J.; Potter, B.; Callender, C.; Sagulenko, P.; Bedford, T.; Neher, R.A. Nextstrain: Real-Time Tracking of Pathogen Evolution. Bioinformatics 2018, 34, 4121-4123. [CrossRef]

21. Rambaut, A.; Holmes, E.C.; O’Toole, Á.; Hill, V.; McCrone, J.T.; Ruis, C.; du Plessis, L.; Pybus, O.G. A Dynamic Nomenclature Proposal for SARS-CoV-2 Lineages to Assist Genomic Epidemiology. Nat. Microbiol. 2020, 5, 1403-1407. [CrossRef]

22. Konings, F.; Perkins, M.D.; Kuhn, J.H.; Pallen, M.J.; Alm, E.J.; Archer, B.N.; Barakat, A.; Bedford, T.; Bhiman, J.N.; Caly, L.; et al. SARS-CoV-2 Variants of Interest and Concern Naming Scheme Conducive for Global Discourse. Nat. Microbiol. 2021, 6, 821-823. [CrossRef]

23. Singh, J.; Pandit, P.; McArthur, A.G.; Banerjee, A.; Mossman, K. Evolutionary Trajectory of SARS-CoV-2 and Emerging Variants. Virol. J. 2021, 18, 166. [CrossRef]

24. WHO. Tracking SARS-CoV-2 Variants. Available online: https://www.who.int/en/activities/tracking-SARS-CoV-2-variants/ (accessed on 2 November 2021).

25. Ferguson, N.; Ghani, A.; Cori, A.; Hogan, A.; Hinsley, W.; Volz, E. Report 49: Growth, Population Distribution and Immune Escape of Omicron in England; Imperial College London: London, UK, 2021. [CrossRef] 
26. Cameroni, E.; Saliba, C.; Bowen, J.E.; Rosen, L.E.; Culap, K.; Pinto, D.; VanBlargan, L.A.; Marco, A.D.; Zepeda, S.K.; di Iulio, J.; et al. Broadly Neutralizing Antibodies Overcome SARS-CoV-2 Omicron Antigenic Shift. Nature 2021. [CrossRef]

27. FDA. SARS-CoV-2 Viral Mutations: Impact on COVID-19 Tests; FDA: Silver Spring, MD, USA, 2021. Available online: https://www. fda.gov/medical-devices / coronavirus-covid-19-and-medical-devices/sars-cov-2-viral-mutations-impact-covid-19-tests (accessed on 23 November 2021).

28. Wille, M.; Holmes, E.C. Wild Birds as Reservoirs for Diverse and Abundant Gamma- and Deltacoronaviruses. FEMS Microbiol. Rev. 2020, 44, 631-644. [CrossRef]

29. Wong, A.C.P.; Li, X.; Lau, S.K.P.; Woo, P.C.Y. Global Epidemiology of Bat Coronaviruses. Viruses 2019, 11, 174. [CrossRef]

30. Li, X.; Wang, L.; Liu, P.; Li, H.; Huo, S.; Zong, K.; Zhu, S.; Guo, Y.; Zhang, L.; Hu, B.; et al. A Novel Potentially Recombinant Rodent Coronavirus with a Polybasic Cleavage Site in the Spike Protein. J. Virol. 2021, 95, e0117321. [CrossRef]

31. Wong, A.C.P.; Lau, S.K.P.; Woo, P.C.Y. Interspecies Jumping of Bat Coronaviruses. Viruses 2021, 13, 2188. [CrossRef]

32. Corman, V.M.; Muth, D.; Niemeyer, D.; Drosten, C. Hosts and Sources of Endemic Human Coronaviruses. Adv. Virus Res. 2018, 100, 163-188. [CrossRef]

33. Fan, Y.; Zhao, K.; Shi, Z.-L.; Zhou, P. Bat Coronaviruses in China. Viruses 2019, 11, 210. [CrossRef]

34. Song, H.-D.; Tu, C.-C.; Zhang, G.-W.; Wang, S.-Y.; Zheng, K.; Lei, L.-C.; Chen, Q.-X.; Gao, Y.-W.; Zhou, H.-Q.; Xiang, H.; et al Cross-Host Evolution of Severe Acute Respiratory Syndrome Coronavirus in Palm Civet and Human. Proc. Natl. Acad. Sci. USA 2005, 102, 2430-2435. [CrossRef]

35. Reusken, C.B.; Haagmans, B.L.; Müller, M.A.; Gutierrez, C.; Godeke, G.-J.; Meyer, B.; Muth, D.; Raj, V.S.; Vries, L.S.-D.; Corman, V.M.; et al. Middle East Respiratory Syndrome Coronavirus Neutralising Serum Antibodies in Dromedary Camels: A Comparative Serological Study. Lancet Infect. Dis. 2013, 13, 859-866. [CrossRef]

36. Xiao, K.; Zhai, J.; Feng, Y.; Zhou, N.; Zhang, X.; Zou, J.-J.; Li, N.; Guo, Y.; Li, X.; Shen, X.; et al. Isolation of SARS-CoV-2-Related Coronavirus from Malayan Pangolins. Nature 2020, 583, 286-289. [CrossRef]

37. Lednicky, J.A.; Tagliamonte, M.S.; White, S.K.; Elbadry, M.A.; Alam, M.M.; Stephenson, C.J.; Bonny, T.S.; Loeb, J.C.; Telisma, T.; Chavannes, S.; et al. Emergence of Porcine Delta-Coronavirus Pathogenic Infections among Children in Haiti through Independent Zoonoses and Convergent Evolution. medRxiv 2021. [CrossRef]

38. Vlasova, A.N.; Diaz, A.; Damtie, D.; Xiu, L.; Toh, T.-H.; Lee, J.S.-Y.; Saif, L.J.; Gray, G.C. Novel Canine Coronavirus Isolated from a Hospitalized Pneumonia Patient, East Malaysia. Clin. Infect. Dis. 2021, ciab456. [CrossRef]

39. Vijgen, L.; Keyaerts, E.; Moës, E.; Thoelen, I.; Wollants, E.; Lemey, P.; Vandamme, A.-M.; Van Ranst, M. Complete Genomic Sequence of Human Coronavirus OC43: Molecular Clock Analysis Suggests a Relatively Recent Zoonotic Coronavirus Transmission Event. J. Virol. 2005, 79, 1595-1604. [CrossRef]

40. Li, W.; Hulswit, R.J.G.; Kenney, S.P.; Widjaja, I.; Jung, K.; Alhamo, M.A.; van Dieren, B.; van Kuppeveld, F.J.M.; Saif, L.J.; Bosch, B.-J. Broad Receptor Engagement of an Emerging Global Coronavirus May Potentiate Its Diverse Cross-Species Transmissibility. Proc. Natl. Acad. Sci. USA 2018, 115, E5135-E5143. [CrossRef]

41. Boley, P.A.; Alhamo, M.A.; Lossie, G.; Yadav, K.K.; Vasquez-Lee, M.; Saif, L.J.; Kenney, S.P. Porcine Deltacoronavirus Infection and Transmission in Poultry, United States. Emerg. Infect. Dis. 2020, 26, 255-265. [CrossRef]

42. Graham, R.L.; Baric, R.S. Recombination, Reservoirs, and the Modular Spike: Mechanisms of Coronavirus Cross-Species Transmission. J. Virol. 2010, 84, 3134-3146. [CrossRef]

43. Menachery, V.D.; Yount, B.L.; Sims, A.C.; Debbink, K.; Agnihothram, S.S.; Gralinski, L.E.; Graham, R.L.; Scobey, T.; Plante, J.A.; Royal, S.R.; et al. SARS-like WIV1-CoV Poised for Human Emergence. Proc. Natl. Acad. Sci. USA 2016, 113, 3048-3053. [CrossRef]

44. Menachery, V.D.; Yount, B.L.; Debbink, K.; Agnihothram, S.; Gralinski, L.E.; Plante, J.A.; Graham, R.L.; Scobey, T.; Ge, X.-Y.; Donaldson, E.F.; et al. A SARS-like Cluster of Circulating Bat Coronaviruses Shows Potential for Human Emergence. Nat. Med. 2015, 21, 1508-1513. [CrossRef]

45. Li, W.; Wong, S.-K.; Li, F.; Kuhn, J.H.; Huang, I.-C.; Choe, H.; Farzan, M. Animal Origins of the Severe Acute Respiratory Syndrome Coronavirus: Insight from ACE2-S-Protein Interactions. J. Virol. 2006, 80, 4211-4219. [CrossRef] [PubMed]

46. Temmam, S.; Vongphayloth, K.; Salazar, E.B.; Munier, S.; Bonomi, M.; Régnault, B.; Douangboubpha, B.; Karami, Y.; Chretien, D.; Sanamxay, D.; et al. Coronaviruses with a SARS-CoV-2-like Receptor-Binding Domain Allowing ACE2-Mediated Entry into Human Cells Isolated from Bats of Indochinese Peninsula. ResearchSquare 2021. [CrossRef]

47. Olival, K.J.; Cryan, P.M.; Amman, B.R.; Baric, R.S.; Blehert, D.S.; Brook, C.E.; Calisher, C.H.; Castle, K.T.; Coleman, J.T.H.; Daszak, P.; et al. Possibility for Reverse Zoonotic Transmission of SARS-CoV-2 to Free-Ranging Wildlife: A Case Study of Bats. PLoS Pathog. 2020, 16, e1008758. [CrossRef] [PubMed]

48. Palmer, M.V.; Martins, M.; Falkenberg, S.; Buckley, A.; Caserta, L.C.; Mitchell, P.K.; Cassmann, E.D.; Rollins, A.; Zylich, N.C.; Renshaw, R.W.; et al. Susceptibility of White-Tailed Deer (Odocoileus Virginianus) to SARS-CoV-2. J. Virol. 2021, 95, e00083-21. [CrossRef]

49. Oude Munnink, B.B.; Sikkema, R.S.; Nieuwenhuijse, D.F.; Molenaar, R.J.; Munger, E.; Molenkamp, R.; van der Spek, A.; Tolsma, P.; Rietveld, A.; Brouwer, M.; et al. Transmission of SARS-CoV-2 on Mink Farms between Humans and Mink and Back to Humans. Science 2021, 371, 172-177. [CrossRef]

50. Hoffmann, M.; Zhang, L.; Krüger, N.; Graichen, L.; Kleine-Weber, H.; Hofmann-Winkler, H.; Kempf, A.; Nessler, S.; Riggert, J.; Winkler, M.S.; et al. SARS-CoV-2 Mutations Acquired in Mink Reduce Antibody-Mediated Neutralization. Cell Rep. 2021, 35, 109017. [CrossRef] [PubMed] 
51. Cui, J.; Li, F.; Shi, Z.-L. Origin and Evolution of Pathogenic Coronaviruses. Nat. Rev. Microbiol. 2019, 17, 181-192. [CrossRef]

52. Nikolaidis, M.; Markoulatos, P.; Van de Peer, Y.; Oliver, S.G.; Amoutzias, G.D. The Neighborhood of the Spike Gene Is a Hotspot for Modular Intertypic Homologous and Non-Homologous Recombination in Coronavirus Genomes. Mol. Biol. Evol. 2021, msab292. [CrossRef]

53. Lauber, C.; Goeman, J.J.; Parquet, M.D.C.; Thi Nga, P.; Snijder, E.J.; Morita, K.; Gorbalenya, A.E. The Footprint of Genome Architecture in the Largest Genome Expansion in RNA Viruses. PLoS Pathog. 2013, 9, e1003500. [CrossRef]

54. Hartenian, E.; Nandakumar, D.; Lari, A.; Ly, M.; Tucker, J.M.; Glaunsinger, B.A. The Molecular Virology of Coronaviruses. J. Biol. Chem. 2020, 295, 12910-12934. [CrossRef]

55. Phillips, J.J.; Chua, M.M.; Lavi, E.; Weiss, S.R. Pathogenesis of Chimeric MHV4/MHV-A59 Recombinant Viruses: The Murine Coronavirus Spike Protein Is a Major Determinant of Neurovirulence. J. Virol. 1999, 73, 7752-7760. [CrossRef] [PubMed]

56. Sánchez, C.M.; Izeta, A.; Sánchez-Morgado, J.M.; Alonso, S.; Sola, I.; Balasch, M.; Plana-Durán, J.; Enjuanes, L. Targeted Recombination Demonstrates That the Spike Gene of Transmissible Gastroenteritis Coronavirus Is a Determinant of Its Enteric Tropism and Virulence. J. Virol. 1999, 73, 7607-7618. [CrossRef] [PubMed]

57. Casais, R.; Dove, B.; Cavanagh, D.; Britton, P. Recombinant Avian Infectious Bronchitis Virus Expressing a Heterologous Spike Gene Demonstrates That the Spike Protein Is a Determinant of Cell Tropism. J. Virol. 2003, 77, 9084-9089. [CrossRef]

58. Rottier, P.J.M.; Nakamura, K.; Schellen, P.; Volders, H.; Haijema, B.J. Acquisition of Macrophage Tropism during the Pathogenesis of Feline Infectious Peritonitis Is Determined by Mutations in the Feline Coronavirus Spike Protein. J. Virol. 2005, 79, 14122-14130. [CrossRef]

59. Kuo, L.; Godeke, G.J.; Raamsman, M.J.; Masters, P.S.; Rottier, P.J. Retargeting of Coronavirus by Substitution of the Spike Glycoprotein Ectodomain: Crossing the Host Cell Species Barrier. J. Virol. 2000, 74, 1393-1406. [CrossRef] [PubMed]

60. Fang, P.; Fang, L.; Zhang, H.; Xia, S.; Xiao, S. Functions of Coronavirus Accessory Proteins: Overview of the State of the Art. Viruses 2021, 13, 1139. [CrossRef] [PubMed]

61. Ren, Y.; Shu, T.; Wu, D.; Mu, J.; Wang, C.; Huang, M.; Han, Y.; Zhang, X.-Y.; Zhou, W.; Qiu, Y.; et al. The ORF3a Protein of SARS-CoV-2 Induces Apoptosis in Cells. Cell Mol. Immunol. 2020, 17, 881-883. [CrossRef] [PubMed]

62. Lee, J.-G.; Huang, W.; Lee, H.; van de Leemput, J.; Kane, M.A.; Han, Z. Characterization of SARS-CoV-2 Proteins Reveals Orf6 Pathogenicity, Subcellular Localization, Host Interactions and Attenuation by Selinexor. Cell Biosci. 2021, 11, 58. [CrossRef]

63. Shang, J.; Han, N.; Chen, Z.; Peng, Y.; Li, L.; Zhou, H.; Ji, C.; Meng, J.; Jiang, T.; Wu, A. Compositional Diversity and Evolutionary Pattern of Coronavirus Accessory Proteins. Brief. Bioinform. 2021, 22, 1267-1278. [CrossRef]

64. Eckerle, L.D.; Lu, X.; Sperry, S.M.; Choi, L.; Denison, M.R. High Fidelity of Murine Hepatitis Virus Replication Is Decreased in Nsp14 Exoribonuclease Mutants. J. Virol. 2007, 81, 12135-12144. [CrossRef]

65. Gribble, J.; Stevens, L.J.; Agostini, M.L.; Anderson-Daniels, J.; Chappell, J.D.; Lu, X.; Pruijssers, A.J.; Routh, A.L.; Denison, M.R. The Coronavirus Proofreading Exoribonuclease Mediates Extensive Viral Recombination. PLoS Pathog. 2021, 17, e1009226. [CrossRef] [PubMed]

66. Crotty, S.; Cameron, C.E.; Andino, R. RNA Virus Error Catastrophe: Direct Molecular Test by Using Ribavirin. Proc. Natl. Acad. Sci. USA 2001, 98, 6895-6900. [CrossRef]

67. Domingo, E.; Perales, C. Viral Quasispecies. PLoS Genet 2019, 15, e1008271. [CrossRef]

68. Borges, V.; Alves, M.J.; Amicone, M.; Isidro, J.; Zé-Zé, L.; Duarte, S.; Vieira, L.; Guiomar, R.; Gomes, J.P.; Gordo, I. Mutation Rate of SARS-CoV-2 and Emergence of Mutators during Experimental Evolution. bioRxiv 2021. [CrossRef]

69. Sanjuán, R.; Nebot, M.R.; Chirico, N.; Mansky, L.M.; Belshaw, R. Viral Mutation Rates. J. Virol. 2010, 84, 9733-9748. [CrossRef]

70. Eigen, M. Error Catastrophe and Antiviral Strategy. Proc. Natl. Acad. Sci. USA 2002, 99, 13374-13376. [CrossRef] [PubMed]

71. Sheahan, T.P.; Sims, A.C.; Zhou, S.; Graham, R.L.; Pruijssers, A.J.; Agostini, M.L.; Leist, S.R.; Schäfer, A.; Dinnon, K.H.; Stevens, L.J.; et al. An Orally Bioavailable Broad-Spectrum Antiviral Inhibits SARS-CoV-2 in Human Airway Epithelial Cell Cultures and Multiple Coronaviruses in Mice. Sci. Transl. Med. 2020, 12, eabb5883. [CrossRef] [PubMed]

72. Malone, B.; Campbell, E.A. Molnupiravir: Coding for Catastrophe. Nat. Struct. Mol. Biol. 2021, 28, 706-708. [CrossRef]

73. Zhou, B.; Thao, T.T.N.; Hoffmann, D.; Taddeo, A.; Ebert, N.; Labroussaa, F.; Pohlmann, A.; King, J.; Steiner, S.; Kelly, J.N.; et al. SARS-CoV-2 Spike D614G Change Enhances Replication and Transmission. Nature 2021, 592, 122-127. [CrossRef] [PubMed]

74. Korber, B.; Fischer, W.M.; Gnanakaran, S.; Yoon, H.; Theiler, J.; Abfalterer, W.; Hengartner, N.; Giorgi, E.E.; Bhattacharya, T.; Foley, B.; et al. Tracking Changes in SARS-CoV-2 Spike: Evidence That D614G Increases Infectivity of the COVID-19 Virus. Cell 2020, 182, 812-827.e19. [CrossRef]

75. Harvey, W.T.; Carabelli, A.M.; Jackson, B.; Gupta, R.K.; Thomson, E.C.; Harrison, E.M.; Ludden, C.; Reeve, R.; Rambaut, A.; COVID-19 Genomics UK (COG-UK) Consortium; et al. SARS-CoV-2 Variants, Spike Mutations and Immune Escape. Nat. Rev. Microbiol. 2021, 19, 409-424. [CrossRef] [PubMed]

76. Boni, M.F.; Lemey, P.; Jiang, X.; Lam, T.T.-Y.; Perry, B.W.; Castoe, T.A.; Rambaut, A.; Robertson, D.L. Evolutionary Origins of the SARS-CoV-2 Sarbecovirus Lineage Responsible for the COVID-19 Pandemic. Nat. Microbiol. 2020, 5, 1408-1417. [CrossRef] [PubMed]

77. Neches, R.Y.; McGee, M.D.; Kyrpides, N.C. Recombination Should Not Be an Afterthought. Nat. Rev. Microbiol. 2020, 18, 606 [CrossRef] [PubMed]

78. Worobey, M.; Pekar, J.; Larsen, B.B.; Nelson, M.I.; Hill, V.; Joy, J.B.; Rambaut, A.; Suchard, M.A.; Wertheim, J.O.; Lemey, P. The Emergence of SARS-CoV-2 in Europe and North America. Science 2020, 370, 564-570. [CrossRef] [PubMed] 
79. Kemp, S.A.; Collier, D.A.; Datir, R.P.; Ferreira, I.A.T.M.; Gayed, S.; Jahun, A.; Hosmillo, M.; Rees-Spear, C.; Mlcochova, P.; Lumb, I.U.; et al. SARS-CoV-2 Evolution during Treatment of Chronic Infection. Nature 2021, 592, 277-282. [CrossRef]

80. Volz, E.; Hill, V.; McCrone, J.T.; Price, A.; Jorgensen, D.; O’Toole, Á.; Southgate, J.; Johnson, R.; Jackson, B.; Nascimento, F.F.; et al. Evaluating the Effects of SARS-CoV-2 Spike Mutation D614G on Transmissibility and Pathogenicity. Cell 2021, 184, 64-75.e11. [CrossRef]

81. Aiewsakun, P.; Katzourakis, A. Time-Dependent Rate Phenomenon in Viruses. J. Virol. 2016, 90, 7184-7195. [CrossRef]

82. MacLean, O.A.; Lytras, S.; Weaver, S.; Singer, J.B.; Boni, M.F.; Lemey, P.; Kosakovsky Pond, S.L.; Robertson, D.L. Natural Selection in the Evolution of SARS-CoV-2 in Bats Created a Generalist Virus and Highly Capable Human Pathogen. PLoS Biol. 2021, 19, e3001115. [CrossRef]

83. Morel, B.; Barbera, P.; Czech, L.; Bettisworth, B.; Hübner, L.; Lutteropp, S.; Serdari, D.; Kostaki, E.-G.; Mamais, I.; Kozlov, A.M.; et al. Phylogenetic Analysis of SARS-CoV-2 Data Is Difficult. Mol. Biol. Evol. 2021, 38, 1777-1791. [CrossRef]

84. Jaroszewski, L.; Iyer, M.; Alisoltani, A.; Sedova, M.; Godzik, A. The Interplay of SARS-CoV-2 Evolution and Constraints Imposed by the Structure and Functionality of Its Proteins. PLoS Comput. Biol. 2021, 17, e1009147. [CrossRef]

85. Mei, H.; Kosakovsky Pond, S.; Nekrutenko, A. Stepwise Evolution and Exceptional Conservation of ORF1a/b Overlap in Coronaviruses. Mol. Biol. Evol. 2021, 38, 5678-5684. [CrossRef]

86. van Dorp, L.; Acman, M.; Richard, D.; Shaw, L.P.; Ford, C.E.; Ormond, L.; Owen, C.J.; Pang, J.; Tan, C.C.S.; Boshier, F.A.T.; et al. Emergence of Genomic Diversity and Recurrent Mutations in SARS-CoV-2. Infect. Genet. Evol. 2020, 83, 104351. [CrossRef]

87. Garushyants, S.K.; Rogozin, I.B.; Koonin, E.V. Insertions in SARS-CoV-2 Genome Caused by Template Switch and Duplications Give Rise to New Variants of Potential Concern. bioRxiv 2021. [CrossRef]

88. Yang, J.; Zhang, G.; Yu, D.; Cao, R.; Wu, X.; Ling, Y.; Pan, Y.-H.; Yi, C.; Sun, X.; Sun, B.; et al. A Kozak-Related Non-Coding Deletion Effectively Increases B.1.1.7 Transmissibility. bioRxiv 2021. [CrossRef]

89. Gussow, A.B.; Auslander, N.; Faure, G.; Wolf, Y.I.; Zhang, F.; Koonin, E.V. Genomic Determinants of Pathogenicity in SARS-CoV-2 and Other Human Coronaviruses. Proc. Natl. Acad. Sci. USA 2020, 117, 15193-15199. [CrossRef]

90. Peacock, T.P.; Goldhill, D.H.; Zhou, J.; Baillon, L.; Frise, R.; Swann, O.C.; Kugathasan, R.; Penn, R.; Brown, J.C.; Sanchez-David, R.Y.; et al. The Furin Cleavage Site in the SARS-CoV-2 Spike Protein Is Required for Transmission in Ferrets. Nat. Microbiol. 2021, 6, 899-909. [CrossRef]

91. Peacock, T.P.; Sheppard, C.M.; Brown, J.C.; Goonawardane, N.; Zhou, J.; Whiteley, M.; PHE Virology Consortium; de Silva, T.I.; Barclay, W.S. The SARS-CoV-2 Variants Associated with Infections in India, B.1.617, Show Enhanced Spike Cleavage by Furin. bioRxiv 2021. [CrossRef]

92. Ntountoumi, C.; Vlastaridis, P.; Mossialos, D.; Stathopoulos, C.; Iliopoulos, I.; Promponas, V.; Oliver, S.G.; Amoutzias, G.D. Low Complexity Regions in the Proteins of Prokaryotes Perform Important Functional Roles and Are Highly Conserved. Nucleic Acids Res. 2019, 47, 9998-10009. [CrossRef] [PubMed]

93. Conceicao, C.; Thakur, N.; Human, S.; Kelly, J.T.; Logan, L.; Bialy, D.; Bhat, S.; Stevenson-Leggett, P.; Zagrajek, A.K.; Hollinghurst, P.; et al. The SARS-CoV-2 Spike Protein Has a Broad Tropism for Mammalian ACE2 Proteins. PLoS Biol. 2020, 18, e3001016. [CrossRef] [PubMed]

94. Ge, X.-Y.; Li, J.-L.; Yang, X.-L.; Chmura, A.A.; Zhu, G.; Epstein, J.H.; Mazet, J.K.; Hu, B.; Zhang, W.; Peng, C.; et al. Isolation and Characterization of a Bat SARS-like Coronavirus That Uses the ACE2 Receptor. Nature 2013, 503, 535-538. [CrossRef]

95. Goldstein, S.A.; Brown, J.; Pedersen, B.S.; Quinlan, A.R.; Elde, N.C. Extensive Recombination-Driven Coronavirus Diversification Expands the Pool of Potential Pandemic Pathogens. bioRxiv 2021. [CrossRef]

96. Simon-Loriere, E.; Holmes, E.C. Why Do RNA Viruses Recombine? Nat. Rev. Microbiol. 2011, 9, 617-626. [CrossRef] [PubMed]

97. Su, S.; Wong, G.; Shi, W.; Liu, J.; Lai, A.C.K.; Zhou, J.; Liu, W.; Bi, Y.; Gao, G.F. Epidemiology, Genetic Recombination, and Pathogenesis of Coronaviruses. Trends Microbiol. 2016, 24, 490-502. [CrossRef]

98. Lau, S.K.P.; Wong, E.Y.M.; Tsang, C.-C.; Ahmed, S.S.; Au-Yeung, R.K.H.; Yuen, K.-Y.; Wernery, U.; Woo, P.C.Y. Discovery and Sequence Analysis of Four Deltacoronaviruses from Birds in the Middle East Reveal Interspecies Jumping with Recombination as a Potential Mechanism for Avian-to-Avian and Avian-to-Mammalian Transmission. J. Virol. 2018, 92, e00265-18. [CrossRef] [PubMed]

99. Makino, S.; Keck, J.G.; Stohlman, S.A.; Lai, M.M. High-Frequency RNA Recombination of Murine Coronaviruses. J. Virol. 1986, 57, 729-737. [CrossRef] [PubMed]

100. Sawicki, S.G.; Sawicki, D.L.; Siddell, S.G. A Contemporary View of Coronavirus Transcription. J. Virol. 2007, 81, 20-29. [CrossRef] [PubMed]

101. Sola, I.; Almazán, F.; Zúñiga, S.; Enjuanes, L. Continuous and Discontinuous RNA Synthesis in Coronaviruses. Annu. Rev. Virol. 2015, 2, 265-288. [CrossRef]

102. Graham, R.L.; Deming, D.J.; Deming, M.E.; Yount, B.L.; Baric, R.S. Evaluation of a Recombination-Resistant Coronavirus as a Broadly Applicable, Rapidly Implementable Vaccine Platform. Commun. Biol. 2018, 1, 179. [CrossRef]

103. Forni, D.; Cagliani, R.; Clerici, M.; Sironi, M. Molecular Evolution of Human Coronavirus Genomes. Trends Microbiol. 2017, 25, 35-48. [CrossRef] [PubMed]

104. Decaro, N.; Mari, V.; Campolo, M.; Lorusso, A.; Camero, M.; Elia, G.; Martella, V.; Cordioli, P.; Enjuanes, L.; Buonavoglia, C. Recombinant Canine Coronaviruses Related to Transmissible Gastroenteritis Virus of Swine Are Circulating in Dogs. J. Virol. 2009, 83, 1532-1537. [CrossRef] 
105. Tian, P.-F.; Jin, Y.-L.; Xing, G.; Qv, L.-L.; Huang, Y.-W.; Zhou, J.-Y. Evidence of Recombinant Strains of Porcine Epidemic Diarrhea Virus, United States, 2013. Emerg. Infect. Dis. 2014, 20, 1735-1738. [CrossRef]

106. Dudas, G.; Rambaut, A. MERS-CoV Recombination: Implications about the Reservoir and Potential for Adaptation. Virus Evol. 2016, 2, vev023. [CrossRef]

107. Bobay, L.-M.; O'Donnell, A.C.; Ochman, H. Recombination Events Are Concentrated in the Spike Protein Region of Betacoronaviruses. PLoS Genet. 2020, 16, e1009272. [CrossRef]

108. Yang, Y.; Yan, W.; Hall, A.B.; Jiang, X. Characterizing Transcriptional Regulatory Sequences in Coronaviruses and Their Role in Recombination. Mol. Biol. Evol. 2021, 38, 1241-1248. [CrossRef] [PubMed]

109. So, R.T.Y.; Chu, D.K.W.; Miguel, E.; Perera, R.A.P.M.; Oladipo, J.O.; Fassi-Fihri, O.; Aylet, G.; Ko, R.L.W.; Zhou, Z.; Cheng, M.-S.; et al. Diversity of Dromedary Camel Coronavirus HKU23 in African Camels Revealed Multiple Recombination Events among Closely Related Betacoronaviruses of the Subgenus Embecovirus. J. Virol. 2019, 93, e01236-19. [CrossRef] [PubMed]

110. Terada, Y.; Matsui, N.; Noguchi, K.; Kuwata, R.; Shimoda, H.; Soma, T.; Mochizuki, M.; Maeda, K. Emergence of Pathogenic Coronaviruses in Cats by Homologous Recombination between Feline and Canine Coronaviruses. PLoS ONE 2014, 9, e106534. [CrossRef] [PubMed]

111. Lytras, S.; Hughes, J.; Martin, D.; de Klerk, A.; Lourens, R.; Kosakovsky Pond, S.L.; Xia, W.; Jiang, X.; Robertson, D.L. Exploring the Natural Origins of SARS-CoV-2 in the Light of Recombination. bioRxiv 2021. [CrossRef]

112. Rubnitz, J.; Subramani, S. The Minimum Amount of Homology Required for Homologous Recombination in Mammalian Cells Mol. Cell. Biol. 1984, 4, 2253-2258. [CrossRef]

113. Banner, L.R.; Lai, M.M. Random Nature of Coronavirus RNA Recombination in the Absence of Selection Pressure. Virology 1991, 185, 441-445. [CrossRef]

114. Pollett, S.; Conte, M.A.; Sanborn, M.; Jarman, R.G.; Lidl, G.M.; Modjarrad, K.; Maljkovic Berry, I. A Comparative Recombination Analysis of Human Coronaviruses and Implications for the SARS-CoV-2 Pandemic. Sci. Rep. 2021, 11, 17365. [CrossRef]

115. Forni, D.; Cagliani, R.; Sironi, M. Recombination and Positive Selection Differentially Shaped the Diversity of Betacoronavirus Subgenera. Viruses 2020, 12, 1313. [CrossRef]

116. Stephens, J.C. On the Frequency of Undetectable Recombination Events. Genetics 1986, 112, 923-926. [CrossRef] [PubMed]

117. Jackson, B.; Boni, M.F.; Bull, M.J.; Colleran, A.; Colquhoun, R.M.; Darby, A.C.; Haldenby, S.; Hill, V.; Lucaci, A.; McCrone, J.T.; et al. Generation and Transmission of Interlineage Recombinants in the SARS-CoV-2 Pandemic. Cell 2021, 184, 5179-5188.e8. [CrossRef] [PubMed]

118. VanInsberghe, D.; Neish, A.S.; Lowen, A.C.; Koelle, K. Recombinant SARS-CoV-2 Genomes Are Currently Circulating at Low Levels. Virus Evol. 2021, 7, veab059. [CrossRef]

119. Turkahia, Y.; Thornlow, B.; Hinrichs, A.; McBroome, J.; Ayala, N.; Ye, C.; De Maio, N.; Haussler, D.; Lanfear, R.; Corbett-Detig, R. Pandemic-Scale Phylogenomics Reveals Elevated Recombination Rates in the SARS-CoV-2 Spike Region. bioRxiv 2021. [CrossRef]

120. Varabyou, A.; Pockrandt, C.; Salzberg, S.L.; Pertea, M. Rapid Detection of Inter-Clade Recombination in SARS-CoV-2 with Bolotie. Genetics 2021, 218, iyab074. [CrossRef]

121. Li, X.; Giorgi, E.E.; Marichannegowda, M.H.; Foley, B.; Xiao, C.; Kong, X.-P.; Chen, Y.; Gnanakaran, S.; Korber, B.; Gao, F. Emergence of SARS-CoV-2 through Recombination and Strong Purifying Selection. Sci. Adv. 2020, 6, eabb9153. [CrossRef]

122. Paraskevis, D.; Kostaki, E.G.; Magiorkinis, G.; Panayiotakopoulos, G.; Sourvinos, G.; Tsiodras, S. Full-Genome Evolutionary Analysis of the Novel Corona Virus (2019-NCoV) Rejects the Hypothesis of Emergence as a Result of a Recent Recombination Event. Infect. Genet. Evol. 2020, 79, 104212. [CrossRef]

123. Patiño-Galindo, J.Á.; Filip, I.; Chowdhury, R.; Maranas, C.D.; Sorger, P.K.; AlQuraishi, M.; Rabadan, R. Recombination and Lineage-Specific Mutations Linked to the Emergence of SARS-CoV-2. Genome Med. 2021, 13, 124. [CrossRef]

124. Robertson, D.L.; Hahn, B.H.; Sharp, P.M. Recombination in AIDS Viruses. J. Mol. Evol. 1995, 40, 249-259. [CrossRef]

125. Boniotti, M.B.; Papetti, A.; Lavazza, A.; Alborali, G.; Sozzi, E.; Chiapponi, C.; Faccini, S.; Bonilauri, P.; Cordioli, P.; Marthaler, D. Porcine Epidemic Diarrhea Virus and Discovery of a Recombinant Swine Enteric Coronavirus, Italy. Emerg. Infect. Dis. 2016, 22, 83-87. [CrossRef]

126. Banerjee, A.; Doxey, A.C.; Tremblay, B.J.-M.; Mansfield, M.J.; Subudhi, S.; Hirota, J.A.; Miller, M.S.; McArthur, A.G.; Mubareka, S.; Mossman, K. Predicting the Recombination Potential of Severe Acute Respiratory Syndrome Coronavirus 2 and Middle East Respiratory Syndrome Coronavirus. J. Gen. Virol. 2020, 101, 1251-1260. [CrossRef]

127. Yount, B.; Roberts, R.S.; Lindesmith, L.; Baric, R.S. Rewiring the Severe Acute Respiratory Syndrome Coronavirus (SARS-CoV) Transcription Circuit: Engineering a Recombination-Resistant Genome. Proc. Natl. Acad. Sci. USA 2006, 103, 12546-12551. [CrossRef]

128. Burns, C.C.; Shaw, J.; Jorba, J.; Bukbuk, D.; Adu, F.; Gumede, N.; Pate, M.A.; Abanida, E.A.; Gasasira, A.; Iber, J.; et al. Multiple Independent Emergences of Type 2 Vaccine-Derived Polioviruses during a Large Outbreak in Northern Nigeria. J. Virol. 2013, 87, 4907-4922. [CrossRef]

129. Guillot, S.; Caro, V.; Cuervo, N.; Korotkova, E.; Combiescu, M.; Persu, A.; Aubert-Combiescu, A.; Delpeyroux, F.; Crainic, R. Natural Genetic Exchanges between Vaccine and Wild Poliovirus Strains in Humans. J. Virol. 2000, 74, 8434-8443. [CrossRef]

130. Pliaka, V.; Kyriakopoulou, Z.; Markoulatos, P. Risks Associated with the Use of Live-Attenuated Vaccine Poliovirus Strains and the Strategies for Control and Eradication of Paralytic Poliomyelitis. Expert Rev. Vaccines 2012, 11, 609-628. [CrossRef] [PubMed] 
131. Karakasiliotis, I.; Paximadi, E.; Markoulatos, P. Evolution of a Rare Vaccine-Derived Multirecombinant Poliovirus. J. Gen. Virol. 2005, 86, 3137-3142. [CrossRef] [PubMed]

132. Kyriakopoulou, Z.; Pliaka, V.; Amoutzias, G.D.; Markoulatos, P. Recombination among Human Non-Polio Enteroviruses: Implications for Epidemiology and Evolution. Virus Genes 2015, 50, 177-188. [CrossRef] [PubMed]

133. Nikolaidis, M.; Mimouli, K.; Kyriakopoulou, Z.; Tsimpidis, M.; Tsakogiannis, D.; Markoulatos, P.; Amoutzias, G.D. Large-Scale Genomic Analysis Reveals Recurrent Patterns of Intertypic Recombination in Human Enteroviruses. Virology 2019, 526, 72-80. [CrossRef] [PubMed]

134. Schelle, B.; Karl, N.; Ludewig, B.; Siddell, S.G.; Thiel, V. Selective Replication of Coronavirus Genomes That Express Nucleocapsid Protein. J. Virol. 2005, 79, 6620-6630. [CrossRef]

135. Sungsuwan, S.; Jongkaewwattana, A.; Jaru-Ampornpan, P. Nucleocapsid Proteins from Other Swine Enteric Coronaviruses Differentially Modulate PEDV Replication. Virology 2020, 540, 45-56. [CrossRef] [PubMed]

136. Lo, C.-Y.; Tsai, T.-L.; Lin, C.-N.; Lin, C.-H.; Wu, H.-Y. Interaction of Coronavirus Nucleocapsid Protein with the 5'- and 3'-Ends of the Coronavirus Genome Is Involved in Genome Circularization and Negative-Strand RNA Synthesis. FEBS J. 2019, 286, 3222-3239. [CrossRef] [PubMed]

137. Ziv, O.; Price, J.; Shalamova, L.; Kamenova, T.; Goodfellow, I.; Weber, F.; Miska, E.A. The Short- and Long-Range RNA-RNA Interactome of SARS-CoV-2. Mol. Cell 2020, 80, 1067-1077.e5. [CrossRef]

138. Sola, I.; Mateos-Gomez, P.A.; Almazan, F.; Zuñiga, S.; Enjuanes, L. RNA-RNA and RNA-Protein Interactions in Coronavirus Replication and Transcription. RNA Biol. 2011, 8, 237-248. [CrossRef]

139. Züst, R.; Miller, T.B.; Goebel, S.J.; Thiel, V.; Masters, P.S. Genetic Interactions between an Essential 3' Cis-Acting RNA Pseudoknot, Replicase Gene Products, and the Extreme $3^{\prime}$ End of the Mouse Coronavirus Genome. J. Virol. 2008, 82, 1214-1228. [CrossRef]

140. Gordon, D.E.; Hiatt, J.; Bouhaddou, M.; Rezelj, V.V.; Ulferts, S.; Braberg, H.; Jureka, A.S.; Obernier, K.; Guo, J.Z.; Batra, J.; et al. Comparative Host-Coronavirus Protein Interaction Networks Reveal Pan-Viral Disease Mechanisms. Science 2020, 370 , eabe9403. [CrossRef] [PubMed]

141. Woo, P.C.Y.; Lau, S.K.P.; Lam, C.S.F.; Tsang, A.K.L.; Hui, S.-W.; Fan, R.Y.Y.; Martelli, P.; Yuen, K.-Y. Discovery of a Novel Bottlenose Dolphin Coronavirus Reveals a Distinct Species of Marine Mammal Coronavirus in Gammacoronavirus. J. Virol. 2014, 88, 1318-1331. [CrossRef]

142. Elhaik, E.; Sabath, N.; Graur, D. The "Inverse Relationship between Evolutionary Rate and Age of Mammalian Genes" Is an Artifact of Increased Genetic Distance with Rate of Evolution and Time of Divergence. Mol. Biol. Evol. 2006, 23, 1-3. [CrossRef]

143. Schmitz, J.F.; Bornberg-Bauer, E. Fact or Fiction: Updates on How Protein-Coding Genes Might Emerge de Novo from Previously Non-Coding DNA. F1000Research 2017, 6, 57. [CrossRef]

144. Ouzounis, C.A. A Recent Origin of Orf3a from M Protein across the Coronavirus Lineage Arising by Sharp Divergence. Comput. Struct. Biotechnol. J. 2020, 18, 4093-4102. [CrossRef]

145. Neches, R.Y.; Kyrpides, N.C.; Ouzounis, C.A. Atypical Divergence of SARS-CoV-2 Orf8 from Orf7a within the Coronavirus Lineage Suggests Potential Stealthy Viral Strategies in Immune Evasion. mBio 2021, 12, e03014-20. [CrossRef] [PubMed]

146. Snijder, E.J.; den Boon, J.A.; Horzinek, M.C.; Spaan, W.J. Comparison of the Genome Organization of Toro- and Coronaviruses: Evidence for Two Nonhomologous RNA Recombination Events during Berne Virus Evolution. Virology 1991, 180, 448-452. [CrossRef]

147. Zeng, Q.; Langereis, M.A.; van Vliet, A.L.W.; Huizinga, E.G.; de Groot, R.J. Structure of Coronavirus Hemagglutinin-Esterase Offers Insight into Corona and Influenza Virus Evolution. Proc. Natl. Acad. Sci. USA 2008, 105, 9065-9069. [CrossRef]

148. Caprari, S.; Metzler, S.; Lengauer, T.; Kalinina, O.V. Sequence and Structure Analysis of Distantly-Related Viruses Reveals Extensive Gene Transfer between Viruses and Hosts and among Viruses. Viruses 2015, 7, 5388-5409. [CrossRef]

149. Lang, Y.; Li, W.; Li, Z.; Koerhuis, D.; van den Burg, A.C.S.; Rozemuller, E.; Bosch, B.-J.; van Kuppeveld, F.J.M.; Boons, G.-J.; Huizinga, E.G.; et al. Coronavirus Hemagglutinin-Esterase and Spike Proteins Coevolve for Functional Balance and Optimal Virion Avidity. Proc. Natl. Acad. Sci. USA 2020, 117, 25759-25770. [CrossRef]

150. Wang, W.; Lin, X.-D.; Zhang, H.-L.; Wang, M.-R.; Guan, X.-Q.; Holmes, E.C.; Zhang, Y.-Z. Extensive Genetic Diversity and Host Range of Rodent-Borne Coronaviruses. Virus Evol. 2020, 6, veaa078. [CrossRef] [PubMed]

151. Huang, C.; Liu, W.J.; Xu, W.; Jin, T.; Zhao, Y.; Song, J.; Shi, Y.; Ji, W.; Jia, H.; Zhou, Y.; et al. A Bat-Derived Putative Cross-Family Recombinant Coronavirus with a Reovirus Gene. PLoS Pathog. 2016, 12, e1005883. [CrossRef]

152. Mihindukulasuriya, K.A.; Wu, G.; St Leger, J.; Nordhausen, R.W.; Wang, D. Identification of a Novel Coronavirus from a Beluga Whale by Using a Panviral Microarray. J. Virol. 2008, 82, 5084-5088. [CrossRef]

153. Hu, Z.-M.; Yang, Y.-L.; Xu, L.-D.; Wang, B.; Qin, P.; Huang, Y.-W. Porcine Torovirus (PToV)-A Brief Review of Etiology, Diagnostic Assays and Current Epidemiology. Front. Vet. Sci. 2019, 6, 120. [CrossRef] [PubMed]

154. Shang, P.; Misra, S.; Hause, B.; Fang, Y. A Naturally Occurring Recombinant Enterovirus Expresses a Torovirus Deubiquitinase. J. Virol. 2017, 91, e00450-17. [CrossRef]

155. Higdon, M.M.; Wahl, B.; Jones, C.B.; Rosen, J.G.; Truelove, S.A.; Baidya, A.; Nande, A.A.; ShamaeiZadeh, P.A.; Walter, K.K.; Feikin, D.R.; et al. A Systematic Review of COVID-19 Vaccine Efficacy and Effectiveness against SARS-CoV-2 Infection and Disease. medRxiv 2021. [CrossRef]

156. Zimmer, C.; Corum, J.; Wee, S.-L. Coronavirus Vaccine Tracker. The New York Times. 2022. Available online: https://www.nytimes. com/interactive/2020/science/coronavirus-vaccine-tracker.html (accessed on 23 November 2021). 
157. Ghasemiyeh, P.; Mohammadi-Samani, S.; Firouzabadi, N.; Dehshahri, A.; Vazin, A. A Focused Review on Technologies, Mechanisms, Safety, and Efficacy of Available COVID-19 Vaccines. Int. Immunopharmacol. 2021, 100, 108162. [CrossRef] [PubMed]

158. Lundstrom, K. The Current Status of COVID-19 Vaccines. Front. Genome Ed. 2020, 2, 579297. [CrossRef] [PubMed]

159. Tegally, H.; Wilkinson, E.; Giovanetti, M.; Iranzadeh, A.; Fonseca, V.; Giandhari, J.; Doolabh, D.; Pillay, S.; San, E.J.; Msomi, N.; et al. Detection of a SARS-CoV-2 Variant of Concern in South Africa. Nature 2021, 592, 438-443. [CrossRef] [PubMed]

160. Garcia-Beltran, W.F.; Lam, E.C.; St Denis, K.; Nitido, A.D.; Garcia, Z.H.; Hauser, B.M.; Feldman, J.; Pavlovic, M.N.; Gregory, D.J.; Poznansky, M.C.; et al. Multiple SARS-CoV-2 Variants Escape Neutralization by Vaccine-Induced Humoral Immunity. Cell 2021, 184, 2372-2383.e9. [CrossRef] [PubMed]

161. Zhou, D.; Dejnirattisai, W.; Supasa, P.; Liu, C.; Mentzer, A.J.; Ginn, H.M.; Zhao, Y.; Duyvesteyn, H.M.E.; Tuekprakhon, A.; Nutalai, R.; et al. Evidence of Escape of SARS-CoV-2 Variant B.1.351 from Natural and Vaccine-Induced Sera. Cell 2021, 184, 2348-2361.e6. [CrossRef] [PubMed]

162. Dejnirattisai, W.; Zhou, D.; Supasa, P.; Liu, C.; Mentzer, A.J.; Ginn, H.M.; Zhao, Y.; Duyvesteyn, H.M.E.; Tuekprakhon, A.; Nutalai, R.; et al. Antibody Evasion by the P.1 Strain of SARS-CoV-2. Cell 2021, 184, 2939-2954.e9. [CrossRef] [PubMed]

163. Madhi, S.A.; Baillie, V.; Cutland, C.L.; Voysey, M.; Koen, A.L.; Fairlie, L.; Padayachee, S.D.; Dheda, K.; Barnabas, S.L.; Bhorat, Q.E.; et al. Efficacy of the ChAdOx1 NCoV-19 COVID-19 Vaccine against the B.1.351 Variant. N. Engl. J. Med. 2021, 384, 1885-1898. [CrossRef]

164. Pulliam, J.R.C.; van Schalkwyk, C.; Govender, N.; von Gottberg, A.; Cohen, C.; Groome, M.J.; Dushoff, J.; Mlisana, K.; Moultrie, H. Increased Risk of SARS-CoV-2 Reinfection Associated with Emergence of the Omicron Variant in South Africa. medRxiv 2021. [CrossRef]

165. Martinez, D.R.; Schäfer, A.; Leist, S.R.; De la Cruz, G.; West, A.; Atochina-Vasserman, E.N.; Lindesmith, L.C.; Pardi, N.; Parks, R.; Barr, M.; et al. Chimeric Spike MRNA Vaccines Protect against Sarbecovirus Challenge in Mice. Science 2021, 373, 991-998. [CrossRef]

166. Saunders, K.O.; Lee, E.; Parks, R.; Martinez, D.R.; Li, D.; Chen, H.; Edwards, R.J.; Gobeil, S.; Barr, M.; Mansouri, K.; et al Neutralizing Antibody Vaccine for Pandemic and Pre-Emergent Coronaviruses. Nature 2021, 594, 553-559. [CrossRef] [PubMed]

167. Tan, C.-W.; Chia, W.-N.; Young, B.E.; Zhu, F.; Lim, B.-L.; Sia, W.-R.; Thein, T.-L.; Chen, M.I.-C.; Leo, Y.-S.; Lye, D.C.; et al. Pan-Sarbecovirus Neutralizing Antibodies in BNT162b2-Immunized SARS-CoV-1 Survivors. N. Engl. J. Med. 2021, 385, 1401-1406. [CrossRef] [PubMed]

168. Loyal, L.; Braun, J.; Henze, L.; Kruse, B.; Dingeldey, M.; Reimer, U.; Kern, F.; Schwarz, T.; Mangold, M.; Unger, C.; et al. CrossReactive CD4+ T Cells Enhance SARS-CoV-2 Immune Responses upon Infection and Vaccination. Science 2021, 374, eabh1823. [CrossRef] [PubMed]

169. Deming, D.; Sheahan, T.; Heise, M.; Yount, B.; Davis, N.; Sims, A.; Suthar, M.; Harkema, J.; Whitmore, A.; Pickles, R.; et al. Vaccine Efficacy in Senescent Mice Challenged with Recombinant SARS-CoV Bearing Epidemic and Zoonotic Spike Variants. PLoS Med. 2006, 3, e525. [CrossRef]

170. Piccoli, L.; Park, Y.-J.; Tortorici, M.A.; Czudnochowski, N.; Walls, A.C.; Beltramello, M.; Silacci-Fregni, C.; Pinto, D.; Rosen, L.E.; Bowen, J.E.; et al. Mapping Neutralizing and Immunodominant Sites on the SARS-CoV-2 Spike Receptor-Binding Domain by Structure-Guided High-Resolution Serology. Cell 2020, 183, 1024-1042.e21. [CrossRef] [PubMed]

171. Grifoni, A.; Weiskopf, D.; Ramirez, S.I.; Mateus, J.; Dan, J.M.; Moderbacher, C.R.; Rawlings, S.A.; Sutherland, A.; Premkumar, L.; Jadi, R.S.; et al. Targets of T Cell Responses to SARS-CoV-2 Coronavirus in Humans with COVID-19 Disease and Unexposed Individuals. Cell 2020, 181, 1489-1501.e15. [CrossRef]

172. Dutta, N.K.; Mazumdar, K.; Gordy, J.T. The Nucleocapsid Protein of SARS-CoV-2: A Target for Vaccine Development. J. Virol. 2020, 94, e00647-20. [CrossRef]

173. Harris, P.E.; Brasel, T.; Massey, C.; Herst, C.V.; Burkholz, S.; Lloyd, P.; Blankenberg, T.; Bey, T.M.; Carback, R.; Hodge, T.; et al. A Synthetic Peptide CTL Vaccine Targeting Nucleocapsid Confers Protection from SARS-CoV-2 Challenge in Rhesus Macaques. Vaccines 2021, 9, 520. [CrossRef]

174. Dangi, T.; Class, J.; Palacio, N.; Richner, J.M.; Penaloza MacMaster, P. Combining Spike- and Nucleocapsid-Based Vaccines Improves Distal Control of SARS-CoV-2. Cell Rep. 2021, 36, 109664. [CrossRef]

175. Hong, S.-H.; Oh, H.; Park, Y.W.; Kwak, H.W.; Oh, E.Y.; Park, H.-J.; Kang, K.W.; Kim, G.; Koo, B.-S.; Hwang, E.-H.; et al Immunization with RBD-P2 and N Protects against SARS-CoV-2 in Nonhuman Primates. Sci. Adv. 2021, 7, eabg7156. [CrossRef]

176. Matchett, W.E.; Joag, V.; Stolley, J.M.; Shepherd, F.K.; Quarnstrom, C.F.; Mickelson, C.K.; Wijeyesinghe, S.; Soerens, A.G.; Becker, S.; Thiede, J.M.; et al. Nucleocapsid Vaccine Elicits Spike-Independent SARS-CoV-2 Protective Immunity. J. Immunol. 2021, 207, 376-379. [CrossRef]

177. Chiuppesi, F.; Nguyen, V.H.; Park, Y.; Contreras, H.; Karpinski, V.; Faircloth, K.; Nguyen, J.; Kha, M.; Johnson, D.; Martinez, J.; et al. Synthetic Multiantigen MVA Vaccine COH04S1 Protects Against SARS-CoV-2 in Syrian Hamsters and Non-Human Primates. bioRxiv 2021. [CrossRef]

178. Rammensee, H.-G.; Gouttefangeas, C.; Heidu, S.; Klein, R.; Preuß, B.; Walz, J.S.; Nelde, A.; Haen, S.P.; Reth, M.; Yang, J.; et al. Designing a SARS-CoV-2 T-Cell-Inducing Vaccine for High-Risk Patient Groups. Vaccines 2021, 9, 428. [CrossRef]

179. Swadling, L.; Diniz, M.O.; Schmidt, N.M.; Amin, O.E.; Chandran, A.; Shaw, E.; Pade, C.; Gibbons, J.M.; Le Bert, N.; Tan, A.T.; et al. Pre-Existing Polymerase-Specific T Cells Expand in Abortive Seronegative SARS-CoV-2. Nature 2021. [CrossRef] 
180. Zhou, Y.-W.; Xie, Y.; Tang, L.-S.; Pu, D.; Zhu, Y.-J.; Liu, J.-Y.; Ma, X.-L. Therapeutic Targets and Interventional Strategies in COVID-19: Mechanisms and Clinical Studies. Signal. Transduct. Target. Ther. 2021, 6, 317. [CrossRef]

181. MHRA First Oral Antiviral for COVID-19, Lagevrio (Molnupiravir), Approved by MHRA. Available online: https:/ www.gov. uk/government/news/first-oral-antiviral-for-covid-19-lagevrio-molnupiravir-approved-by-mhra (accessed on 5 November 2021).

182. Szemiel, A.M.; Merits, A.; Orton, R.J.; MacLean, O.A.; Pinto, R.M.; Wickenhagen, A.; Lieber, G.; Turnbull, M.L.; Wang, S.; Furnon, W.; et al. In Vitro Selection of Remdesivir Resistance Suggests Evolutionary Predictability of SARS-CoV-2. PLoS Pathog. 2021, 17, e1009929. [CrossRef] [PubMed]

183. Molla, A.; Korneyeva, M.; Gao, Q.; Vasavanonda, S.; Schipper, P.J.; Mo, H.M.; Markowitz, M.; Chernyavskiy, T.; Niu, P.; Lyons, N.; et al. Ordered Accumulation of Mutations in HIV Protease Confers Resistance to Ritonavir. Nat. Med. 1996, 2, 760-766. [CrossRef] [PubMed]

184. Michelen, M.; Manoharan, L.; Elkheir, N.; Cheng, V.; Dagens, A.; Hastie, C.; O’Hara, M.; Suett, J.; Dahmash, D.; Bugaeva, P.; et al. Characterising Long COVID: A Living Systematic Review. BMJ Glob. Health 2021, 6, e005427. [CrossRef] [PubMed]

185. Al-Aly, Z.; Bowe, B.; Xie, Y. Long COVID after Breakthrough COVID-19: The Post-Acute Sequelae of Breakthrough COVID-19. ResearchSquare 2021. [CrossRef]

186. Kannan, S.R.; Spratt, A.N.; Cohen, A.R.; Naqvi, S.H.; Chand, H.S.; Quinn, T.P.; Lorson, C.L.; Byrareddy, S.N.; Singh, K. Evolutionary Analysis of the Delta and Delta Plus Variants of the SARS-CoV-2 Viruses. J. Autoimmun. 2021, $124,102715$. [CrossRef] [PubMed]

187. Liu, Y.; Liu, J.; Johnson, B.A.; Xia, H.; Ku, Z.; Schindewolf, C.; Widen, S.G.; An, Z.; Weaver, S.C.; Menachery, V.D.; et al. Delta Spike P681R Mutation Enhances SARS-CoV-2 Fitness over Alpha Variant. bioRxiv 2021. [CrossRef]

188. Lubinski, B.; Frazier, L.E.; Phan, M.V.T.; Bugembe, D.L.; Tang, T.; Daniel, S.; Cotten, M.; Jaimes, J.A.; Whittaker, G.R. Spike Protein Cleavage-Activation Mediated by the SARS-CoV-2 P681R Mutation: A Case-Study from Its First Appearance in Variant of Interest (VOI) A.23.1 Identified in Uganda. bioRxiv 2021. [CrossRef]

189. Smaoui, M.R.; Yahyaoui, H. Unraveling the Stability Landscape of Mutations in the SARS-CoV-2 Receptor-Binding Domain. Sci. Rep. 2021, 11, 9166. [CrossRef]

190. Starr, T.N.; Greaney, A.J.; Hilton, S.K.; Ellis, D.; Crawford, K.H.D.; Dingens, A.S.; Navarro, M.J.; Bowen, J.E.; Tortorici, M.A.; Walls, A.C.; et al. Deep Mutational Scanning of SARS-CoV-2 Receptor Binding Domain Reveals Constraints on Folding and ACE2 Binding. Cell 2020, 182, 1295-1310.e20. [CrossRef] [PubMed]

191. Arora, P.; Rocha, C.; Kempf, A.; Nehlmeier, I.; Graichen, L.; Winkler, M.S.; Lier, M.; Schulz, S.; Jäck, H.-M.; Cossmann, A.; et al. The Spike Protein of SARS-CoV-2 Variant A.30 Is Heavily Mutated and Evades Vaccine-Induced Antibodies with High Efficiency. Cell Mol. Immunol. 2021, 18, 2673-2675. [CrossRef] [PubMed]

192. Lau, S.K.P.; Feng, Y.; Chen, H.; Luk, H.K.H.; Yang, W.-H.; Li, K.S.M.; Zhang, Y.-Z.; Huang, Y.; Song, Z.-Z.; Chow, W.-N.; et al Severe Acute Respiratory Syndrome (SARS) Coronavirus ORF8 Protein Is Acquired from SARS-Related Coronavirus from Greater Horseshoe Bats through Recombination. J. Virol. 2015, 89, 10532-10547. [CrossRef] [PubMed]

193. Mohammad, S.; Bouchama, A.; Mohammad Alharbi, B.; Rashid, M.; Saleem Khatlani, T.; Gaber, N.S.; Malik, S.S. SARS-CoV-2 ORF8 and SARS-CoV ORF8ab: Genomic Divergence and Functional Convergence. Pathogens 2020, 9, 677. [CrossRef]

194. Mostaghimi, D.; Valdez, C.N.; Larson, H.T.; Kalinich, C.C.; Iwasaki, A. Prevention of Host-to-Host Transmission by SARS-CoV-2 Vaccines. Lancet Infect. Dis. 2021. [CrossRef]

195. Rella, S.A.; Kulikova, Y.A.; Dermitzakis, E.T.; Kondrashov, F.A. Rates of SARS-CoV-2 Transmission and Vaccination Impact the Fate of Vaccine-Resistant Strains. Sci. Rep. 2021, 11, 15729. [CrossRef]

196. Mallapaty, S.; Callaway, E.; Kozlov, M.; Ledford, H.; Pickrell, J.; Van Noorden, R. How COVID Vaccines Shaped 2021 in Eight Powerful Charts. Nature 2021, 600,580-583. [CrossRef]

197. Zhou, P.; Shi, Z.-L. SARS-CoV-2 Spillover Events. Science 2021, 371, 120-122. [CrossRef] [PubMed]

198. Choi, B.; Choudhary, M.C.; Regan, J.; Sparks, J.A.; Padera, R.F.; Qiu, X.; Solomon, I.H.; Kuo, H.-H.; Boucau, J.; Bowman, K.; et al. Persistence and Evolution of SARS-CoV-2 in an Immunocompromised Host. N. Engl. J. Med. 2020, 383, 2291-2293. [CrossRef] [PubMed] 